\title{
Numerical modelling on fate and transport of petroleum hydrocarbons in an unsaturated subsurface system for varying source scenario
}

\author{
M Berlin ${ }^{1}$, M Vasudevan $^{1}$, G Suresh Kumar $^{2, *}$ and Indumathi M Nambi ${ }^{1}$ \\ ${ }^{1}$ EWRE Division, Department of Civil Engineering, Indian Institute of Technology, \\ Madras, Chennai 600 036, India. \\ ${ }^{2}$ Department of Ocean Engineering, Indian Institute of Technology, Madras, Chennai 600 036, India. \\ *Corresponding author.e-mail: gskumar@iitm.ac.in
}

The vertical transport of petroleum hydrocarbons from a surface spill through an unsaturated subsurface system is of major concern in assessing the vulnerability of groundwater contamination. A realistic representation on fate and transport of volatile organic compounds at different periods after spill is quite challenging due to the variation in the source behaviour at the surface of spill as well as the variation in the hydrodynamic parameters and the associated inter-phase partitioning coefficients within the subsurface. In the present study, a one dimensional numerical model is developed to simulate the transport of benzene in an unsaturated subsurface system considering the effect of volatilization, dissolution, adsorption and microbial degradation of benzene for (i) constant continuous source, (ii) continuous decaying source, and (iii) residual source. The numerical results suggest that volatilization is the important sink for contaminant removal considering the soil air migration within the unsaturated zone. It is also observed that the coupled effect of dissolution and volatilization is important for the decaying source at the surface immediately after the spill, whereas rate-limited dissolution from residually entrapped source is responsible for the extended contamination towards later period.

\section{Introduction}

In many contaminated sites, hazardous organic compounds are found to be trapped in the vadose zone because of sorption by the soil mineral and organic matter, resulting in retardation for their further movement through the aqueous or vapour phase (Baedecker et al. 1993; Lin and Hildemann 1995; Kim et al. 2001; Mayer et al. 2002). However, a majority of the underground storage tank spill studies have focused on the transport of petroleum hydrocarbons as light non-aqueous phase liquid (LNAPL) in saturated flow condition (Choi et al. 2005; Sulaymon and Gzar 2011). Considering the subsequent distribution of NAPL in the subsurface following the spill, volatilization of dominant vapour constituent such as benzene is inevitable. Hence, it is important to estimate the partitioning of spilled organic compounds between nonaqueous, aqueous and vapour phases following the spill in order to assess their fate and transport in contaminated soils, especially in the vadose zone which is beneficial for understanding the associated risk for groundwater contamination, as well as for deciding suitable $i n$-situ remediation techniques such as vapour phase extraction or bio-venting.

Considering the actual fuel spill conditions, it is reported that volatilization and dissolution are the primary weathering mechanisms for highly soluble compounds like benzene. Under transient

Keywords. Benzene; numerical simulation; unsaturated porous media; dissolution; volatilization; adsorption. 
conditions of continual seasonal inputs of rainfall, the migration of the chemicals to the water table will influence its vapour phase transport resulting in more vertical distribution towards the water table. The average first-order weathering rate for benzene is reported as nearly $26 \%$ per year (Kampbell et al. 2001). In fact, a significant portion of spill occurred before being detected and the contaminant plumes are reaching equilibrium before any active remediation takes effect. The data from the site at East Patchogue, New York, contributed a release volume of at least 13,200 gallons, which contains $420 \mathrm{~kg}$ of benzene. Long term monitoring results suggest that the rate of natural attenuation is nearly constant at $0.65 \mathrm{~m} /$ day considering the entire release (Weaver 1996).

The source emplacement study at the Canadian Force Base Borden, Ontario, addressed different aspects of subsurface transport of multi-component and varying source characteristics under controlled conditions, but it is not a good representative of a real spill (Broholm et al. 1999; Frind et al. 1999; Rivett and Feenstra 2005). Similarly, the Bemidji contaminated site has been studied for change in composition of the spilled fuel and modelling results match with monitored data, indicating the significance of rate-limited dissolution at field scale (Baedecker et al. 2011).

Assuming local equilibrium at the interphase, most of the mass transfer processes are described by the partitioning coefficients such as solubility, Henry's constant, and solid-liquid sorption coefficient. Since Henry's law constant for benzene is high, volatilization of benzene from the liquid phase seems to be a major pathway of benzene transport in the moist unsaturated soil (Nassar et al. 1999; Choi et al. 2005). It is also reported that mass reduction by irreversible sorption of benzene is significant for the sandy material during column study (Baek et al. 2003). The presence of moisture content is found to significantly affect the volatilization partitioning coefficient as well as solid-liquid sorption partitioning coefficient (Voudrias and Li 1993; Nassar et al. 1999; Kim et al. 2001). For benzene in the vapour phase, the water-partitioning effect is found to be more significant as water saturation increased with relatively less soil sorption. The reduction in sorption capacity with increasing moisture is attributed to the competition by water molecules due to their high polarity (Voudrias and Li 1993; Popovicova 1996; Kim et al. 2001).

Models for NAPL pool dissolution have typically assumed that dissolution occurs only at the external NAPL pool-aqueous phase interface. However, many researchers have concluded that rate-limited mass transfer is important under certain conditions where (1) groundwater velocities are high,
(2) NAPL saturations are low, and (3) NAPL is distributed as large blobs filling several pores (Miller et al. 1990; Powers et al. 1991; Mayer and Miller 1996). The overall rate of dissolution is typically determined by the slowest of the following three steps: diffusion of constituents through the NAPL phase, dissolution at the interface, and diffusion away from the NAPL-water interface into the bulk water phase.

The bacterial activity is significant in the unsaturated zone of the aquifer because of the aerobic conditions reflected by the abundance of the electron acceptors and sufficient nutrients in the wet soil (Kim et al. 2001; Purandara et al. 2008; Berlin et al. 2013, 2014a, b). Yadav and Hassanizadeh (2011) presented an overview of biodegradation of LNAPLs in coastal (semi)-arid environment. The bio-availability of organic compounds depends on their ability to dissolve into aqueous phase or to sorb at the solid-liquid interface. It is reported that typical in situ remediation technologies including soil venting, soil flushing, and bioremediation are successful techniques for the enhanced biodegradation and complete removal of contaminants from the source (Popovicova 1996). The results from Hinchee et al. (1991) indicated that soil venting enhances biodegradation due to oxygen enrichment of the vadose zone. With few exceptions, bio-venting is found to be successful in decreasing the contaminant level below the detection limit (English and Loehr 1991; Popovicova 1996). The effect of dissolved oxygen transport in the unsaturated zone is found to be significant to enhance the biological transformation of contaminants, apart from its influence on the effective water saturation (Berlin et al. 2014c).

Numerical modelling of rate-limited sorption and dissolution on the transport of petroleum hydrocarbons have been addressed so far by many researchers with emphasis on saturated porous media (Clement et al. 2004; Sulaymon and Gzar 2011; Mastrocicco et al. 2012). A two-dimensional plume test and modelling has been conducted for the investigation of fate and transport of aqueous benzene by considering the possible process such as volatilization and irreversible sorption in saturated sand aquifer column (Choi et al. 2005). Recently, Sulaymon and Gzar (2011) conducted the dissolution and transport of benzene in threedimensional homogeneous, isotropic, and saturated porous media. However, there are limited experimental and numerical modelling studies considering the combined effects of various mass transfer processes in the unsaturated zone. Mass reduction of hydrocarbon compounds by volatilization was reported by Chiang et al. (1989) and Lahvis et al. (1991), who observed volatilization along with biodegradation of BTX (Benzene, Toluene, 
and Xylene) compounds in a shallow aquifer and at gasoline spill sites, respectively.

As observed from the field examples, the extent of spread is much more than monitored, since the actual amount of spill as well as the initial composition of the fuel is unnoticed in many cases, thereby significantly affecting the post-spill management and remediation activities because of misrepresenting the associated risk. The focus of the present work is to understand the simultaneous mass transfer as well as transport processes following the surface spill of benzene in the unsaturated zone, aiming at better concentration profiles, which can be useful in risk-based decision making. The study domain is limited to near-surface environment where soil pores are filled with both air and water. Physical processes selected include moisture infiltration in the subsurface along with dissolved compound; partitioning of the organic compound between NAPL to aqueous, vapour and solid phases and subsequent contamination of the aquifer by the residually trapped NAPL in the unsaturated soil pores. The effect of source zone decay is included in the study, along with bacterial degradation kinetics in the active subsurface zone, for understanding the efficacy of mass removal under mass transfer limited conditions. The parameters for the modelling study can be matched with the field scenario in order to effectively trace the contaminant plume.

\section{Problem definitions and model formulation}

The vertical transport by soil water, of petroleum hydrocarbon coming from spillages, is of major concern in assessing the vulnerability of groundwater contamination. Subsequent to the surface spill of organic compounds, there is high chance of NAPL partitioning to the soil water, which infiltrates through the soil pores according to the pressure head variation. Benzene is selected as a representative volatile organic compound (VOC) because it has a relatively large water solubility (1780 mg/L), large vapour density (325 mg/L), and can be well adsorbed by soil (Nassar et al. 1999; Kim et al. 2001).

The present study addresses the fate and transport of benzene in the dissolved phase which is moving along with infiltrating water. In order to simulate the source removal conditions at different time scales, three different scenarios were selected pertaining to the physical behaviour and source strength from the surface spill of benzene. The first case represents the immediate mass transfer as well as transport of the emanating plume originating from the NAPL pool at the soil surface and represents the conventional constant continuous source. For the second case, continuous source decay is considered at the inter-phase, which serves as the sink term for volatilization or irreversible sorption, and represents the time varying (decreasing) continuous source. The third scenario represents the distributed NAPL source as entrapped in the soil pores causing rate-limited dissolution resulting in extended contamination of the aquifer, and represents the Cauchy boundary condition (summation of advective and dispersive fluxes at the first node equal to zero).

Richard's equation is the most often used model to represent the vertical fluid flow in the unsaturated porous media (Richards 1931; van Genuchten 1980). The one-dimensional non-linear vertical water flow model in an unsaturated porous medium can be derived from classical conservation principles using continuity equation (mass conservation) and Darcy's law (momentum conservation) leading to Richard's equation as expressed in equation (1) (Richards 1931; van Genuchten 1980; Celia et al. 1990; Antonopoulos 2006; Zeng and Decker 2009).

$$
C(h) \frac{\partial h}{\partial t}=\frac{\partial}{\partial z} K\left(\frac{\partial h}{\partial z}\right)-\frac{\partial K}{\partial z}
$$

where $C(h)=\frac{\partial \theta}{\partial h}$ is specific moisture capacity $\left(\mathrm{m}^{-1}\right)$; $h$ is the pressure head $(\mathrm{m}) ; \theta$ is the water content; $K$ is the unsaturated hydraulic conductivity $\left(\mathrm{ms}^{-1}\right) ; t$ is the time $(\mathrm{s})$ and $z$ is the vertical distance $(\mathrm{m})$ positive downward. Since the hydraulic conductivity in the above equation (equation 1) varies significantly with available soil moisture distribution in the vadose zone, it can be expressed as a function of effective saturation and negative pressure head.

Many relationships are available to relate the water content, pressure head, and hydraulic conductivity for unsaturated soil such as Burdine (1953), Brooks and Corey (1964), Mualem (1976), van Genuchten (1980), Fredlund and Xing (1994). Since, the van Genuchten relationship is widely used by many authors (Clement et al. 1994; Lehmann and Ackerer 1998; Van Dam and Feddes 2000; Xiang-Wei et al. 2010), the same relationship is used for the current study, which is given in equations $(2-4)$.

$$
\begin{gathered}
S_{e}=\frac{\theta_{m}-\theta_{r}}{\theta_{s}-\theta_{r}} \\
\theta_{m}=\theta_{r}+\frac{\theta_{s}-\theta_{r}}{\left(1+|\alpha h|^{\beta}\right)^{\eta}} \\
K(h)=K_{s} S_{e}^{1 / 2}\left[1-\left(1 S_{e}^{1 / \eta}\right)^{\eta}\right]^{2}
\end{gathered}
$$


where $\theta_{m}$ is the water content; $S_{e}$ is the effective saturation; $\theta_{s}$ is the saturated water content; $\theta_{r}$ is the residual water content; $K_{s}$ is the saturated hydraulic conductivity $\left(\mathrm{ms}^{-1}\right) ; \alpha, \beta$ and $\eta$ are van Genuchten fitting parameters. These van Genuchten fitting parameters can be obtained from soil-water characteristic curve, which is derived from water content and the corresponding pressure head profile of soil. The soil-water characteristics curve reflects implicitly the various texture and hydraulic properties of soil by van Genuchten parameters.

The solution of water flow model (equation 1) along with constitutive relationships (equations 2-4) provides the pressure head as well as hydraulic conductivity distribution in an unsaturated domain in order to estimate the mean fluid velocity profile. The diffusion of oxygen from the atmosphere to the soil air is considered as an important mass transfer process responsible for maintaining the aerobic condition in the unsaturated zone (Reible et al. 1989). It is assumed to be a continuous process at the inter-phase between soil air and water, which can be described by the air diffusion model (Simunek and Suarez 1994) as given in equation (5).

$\theta_{g}\left[\frac{\partial}{\partial t}\left(\mathrm{O}_{2, \mathrm{~g}}\right)\right]=\theta_{g} D_{0} \frac{\partial}{\partial z}\left[\tau \frac{\partial \mathrm{O}_{2, \mathrm{~g}}}{\partial z}\right] \omega\left(\mathrm{O}_{2}-\frac{1}{\mathrm{H}} \mathrm{O}_{2, \mathrm{~g}}\right)$

where $\mathrm{O}_{2, \mathrm{~g}}$ is the oxygen concentration in the gas phase $(\mathrm{mg} / \mathrm{L}) ; \mathrm{O}_{2}$ is the oxygen concentration in the water phase $(\mathrm{mg} / \mathrm{L}) ; \theta_{g}$ is the volumetric air content $\left(\theta_{g}=\theta_{s}-\theta_{m}\right) ; D_{0}$ is the gas diffusion coefficient $\left(\mathrm{m}^{2} \mathrm{~s}^{-1}\right)$ and $\tau$ is the tortuosity factor. The tortuosity term (Millington 1959) is described in equation (6).

$$
\tau=\frac{\theta_{g}^{7 / 3}}{\theta_{s}^{2}} .
$$

The interphase mass transfer between gas and water phase is proportional to the oxygen solubility in water as explained by Henry's equilibrium law (Alfnes et al. 2004), and is given in equation (7).

$$
\theta_{m}\left[\frac{\partial}{\partial t}\left(\mathrm{O}_{2}\right)\right]_{\text {exchange }}=-\omega\left(\mathrm{O}_{2}-\frac{1}{H} \mathrm{O}_{2, \mathrm{~g}}\right)
$$

where $H$ is the dimensionless Henry law constant, and $\omega$ is the first order gas transfer coefficient $\left(\sec ^{-1}\right)$.

Most of the multi-phase flow models for the subsurface system are based on the non-hysteretic form of pressure-saturation-hydraulic conductivity relationships for the fluid flow, and the mass transfer processes for the transport models are generally represented by local equilibrium or firstorder kinetic reactions (Miller et al. 1990). The reactive transport model is formulated by considering the major reaction sinks such as volatilization, aerobic degradation and sorption of the dissolved contaminant in the infiltrating water. Since the aqueous phase concentration of the contaminant (benzene) can reach the maximum saturation value near the source zone, it can inhibit the substrate utilization by the aerobic bacteria as explained by Haldane-inhibition kinetics (Choi et al. 2005; Kim et al. 2005). Presence of oxygen as the electron acceptor is incorporated in the degradation module in a similar way to the benzene kinetics. Equilibrium partitioning by sorption results in retardation effect for the dissolved plume, as explained by the retardation factor $\left(R=1+\frac{\left(\rho_{b} k_{d}\right)}{\left(\theta_{w}\right)}\right)$. The volatilization is assumed to be a first order reaction having constant rate $\left(\lambda_{\mathrm{vol}}\right)$. The overall transport of dissolved benzene (Choi et al. 2005; Sulaymon and Gzar 2011), considering the above reactions is given by equation (8).

$$
\begin{aligned}
R \frac{\partial C}{\partial t}= & \frac{\partial}{\partial z}\left(D \frac{\partial C}{\partial z}\right)-V \frac{\partial C}{\partial z}-\lambda_{\mathrm{vol}} C \\
& -\frac{\mu_{\max }}{Y}\left[M+\frac{\rho_{\mathrm{s}} M_{\mathrm{s}}}{\theta_{m}}\right]\left[\frac{C}{K_{\mathrm{c}}+C+\frac{C^{2}}{K_{i}}}\right] \\
& \times\left[\frac{\mathrm{O}_{2}}{K_{0}+\mathrm{O}_{2}}\right] .
\end{aligned}
$$

Since the bacteria is assumed to be mobile in the aqueous phase and is subjected to growth and endogenous decay along with additional attachment or detachment towards the solid phase (Choi et al. 2005; Choi et al. 2009; Natarajan and Suresh Kumar 2011), the transport model for the mobile bacteria is given by equation (9).

$$
\begin{aligned}
\frac{\partial M}{\partial t}= & \frac{\partial}{\partial z}\left(D \frac{\partial M}{\partial z}\right)-V \frac{\partial M}{\partial z}-k_{a} M+k_{d} \frac{\rho_{s}}{\theta_{m}} M_{s} \\
& +\mu_{\max } M\left[\frac{C}{K_{c}+C+\frac{c^{2}}{K_{i}}}\right] \\
& \times\left[\frac{\mathrm{O}_{2}}{K_{0}+\mathrm{O}_{2}}\right]-k_{\mathrm{dec}} M
\end{aligned}
$$

Similarly, the portion of the bacteria which is sorbed onto the solid phase is immobile in nature, which is subjected to attachment, detachment, growth and decay, except advective transport with water (Choi et al. 2005; Natarajan and Suresh Kumar 2011) as given in equation (10).

$$
\begin{aligned}
\frac{\partial M_{s}}{\partial t}= & k_{a} \frac{\theta_{m}}{\rho_{s}} M-k_{d} M_{s}+\mu_{\max } M_{s}\left[\frac{C}{K_{c}+C+\frac{C^{2}}{K_{i}}}\right] \\
& \times\left[\frac{\mathrm{O}_{2}}{K_{0}+\mathrm{O}_{2}}\right]+k_{\mathrm{dec}} M_{s} .
\end{aligned}
$$


The dissolved oxygen concentration is found to be varying significantly throughout the domain largely due to the bacterial utilization for the contaminant degradation, in spite of continuous supply from the gaseous phase and subsequent downward transport. Thus the transport of the dissolved oxygen in the subsurface can be represented as given in equation (11)

$$
\begin{aligned}
\frac{\partial \mathrm{O}_{2}}{\partial t}= & \frac{\partial}{\partial z}\left(D \frac{\partial \mathrm{O}_{2}}{\partial z}\right)-V \frac{\partial \mathrm{O}_{2}}{\partial z}-\frac{\mu_{\max }}{Y} F \\
& \times\left[M+\frac{\rho_{s}}{\theta_{m}} M_{s}\right]\left[\frac{C}{K_{c}+C+\frac{C^{2}}{K_{i}}}\right] \\
& \times\left[\frac{\mathrm{O}_{2}}{K_{0}+\mathrm{O}_{2}}\right]-\frac{\omega}{\theta_{m}}\left(\mathrm{O}_{2}-\frac{1}{H} \mathrm{O}_{2, \mathrm{~g}}\right)
\end{aligned}
$$

where $C$ is the benzene concentration in the aqueous phase $(\mathrm{mg} / \mathrm{L}) ; M$ is the concentration of bacteria suspended in the aqueous phase $(\mathrm{mg} / \mathrm{L}) ; M_{s}$ is the mass of bacteria attached on the solid phase per unit mass of solid phase $(\mathrm{mg} / \mathrm{g}) ; D$ is the longitudinal dispersion coefficient (which is expressed as $\left.D=q * \alpha_{L}\right) ; q$ is the Darcy velocity $\left(\mathrm{ms}^{-1}\right) ; v$ is the pore water velocity $\left(\mathrm{ms}^{-1}\right.$ ) (which is expressed as $\left.v=q / \theta_{w}\right) ; \alpha_{L}$ is the longitudinal dispersivity $(\mathrm{m}) ; \rho_{s}$ is the bulk density of soil $(\mathrm{mg} / \mathrm{L}) ; R$ is the retardation factor of benzene; $\lambda_{\mathrm{vol}}$ is the first order decay coefficient of benzene due to volatilization $\left(\mathrm{s}^{-1}\right) ; \mu_{\max }$ is the maximum specific growth rate of bacteria $\left(\mathrm{s}^{-1}\right) ; K_{c}$ is the half saturation constant of benzene $(\mathrm{mg} / \mathrm{L}) ; Y$ is the bacterial yield coefficient; $K_{a}$ is the bacterial attachment rate coefficient $\left(\mathrm{s}^{-1}\right) ; K_{d}$ is the bacterial detachment rate coefficient $\left(\mathrm{s}^{-1}\right) ; k_{\text {dec }}$ is the bacterial death rate coefficient $\left(\mathrm{s}^{-1}\right) ; F$ is the oxygen use coefficient; $K_{i}$ is the Haldane inhibition constant of benzene $(\mathrm{mg} / \mathrm{L})$ and $K_{0}$ is the half saturation constant of oxygen $(\mathrm{mg} / \mathrm{L})$.

In order to model the rate-limited dissolution from the residually entrapped pores, a common linear driving force model is applied here (equation 12) which is to be incorporated in equation (8) as a source term.

$$
\left(\frac{\partial C}{\partial t}\right)_{\text {dissolution }}=K_{n w}\left(C_{\text {sat }}-C\right)
$$

where $K_{n w}$ represents the lumped dissolution mass transfer coefficient from non-aqueous phase to aqueous phase $\left(\mathrm{s}^{-1}\right)$ and $C_{\text {sat }}$ is the saturated concentration in the aqueous phase $(\mathrm{mg} / \mathrm{L})$. The mass transfer coefficient, which is a function of various system properties such as residual saturation, particle size, and porosity, can be represented in a dimensionless form as given below in equation (13)
(Powers et al. 1994; Schaerlaekens et al. 2000; Nambi and Powers 2003)

$$
K_{n w}=\frac{S h^{\prime} D_{m}}{d_{p}^{2}}
$$

where $S h^{\prime}$ is the modified Sherwood number, $D_{m}$ is molecular diffusion coefficient of organic compound $\left(\mathrm{m}^{2} \mathrm{~s}^{-1}\right), d_{p}$ is mean particle size of the porous medium (m). Sherwood number is the ratio of reaction rate to the diffusion rate, relating interphase to molecular mass transport resistances. There are numerous correlations existing for the estimation of $K_{n w}$ in terms of $S h^{\prime}$ as a function of flow and NAPL properties (Miller et al. 1990; Powers et al. 1994; Mayer and Miller 1996; Nambi and Powers 2003). The correlation developed by Nambi and Powers (2003) (equation 14) has been selected for the present study because of its efficiency to handle wide range of residual saturation conditions.

$$
S h^{\prime}=37.15 \operatorname{Re}^{0.61} S_{n}^{1.24}
$$

where Re is the Reynolds number and $S_{n}$ is the non-aqueous phase residual saturation. From the literature, it is understood that there is no direct correlation available for Sherwood number for NAPL dissolution specifically accounting for aerobic/anaerobic conditions. However, few studies have accounted the Sherwood number to represent the dissolution rate under various circumstances including aerobic and anaerobic conditions (Unger et al. 1998; Yang and McCarty 2000; Vasudevan et al. 2014). Especially, Chu et al. (2007) have represented the dissolution rate in terms of Sherwood number, where aerobic biodegradation is considered. In this context, equation (14) is assumed to be valid for aerobic as well as anaerobic conditions.

The initial and boundary conditions pertaining to the model equations $(1,5,8,9,10$ and 11) are given in table 1 . The initial and boundary conditions for the three selected cases for the benzene transport model are also given in table 1 . The selected model parameters for the unsaturated zone moisture infiltration model are given in table 2. The bio-kinetic reaction parameters for benzene are given in table 3 . It is assumed that multi-phase transport of soil air as well as contaminant occurs simultaneously in the available pore volume which is facilitating the contaminant degradation.

\section{Numerical solution}

In the present system, the aqueous phase transport of dissolved benzene and bacteria along with water and air flow have been described by a set of partial differential equations. The popular method of 
Table 1. Selected initial and boundary conditions.

\begin{tabular}{|c|c|c|}
\hline Model & Initial condition & Boundary conditions \\
\hline Water flow model & $\mathrm{h}(\mathrm{t}=0, \mathrm{z})=-75 \mathrm{~cm}$ & $\begin{array}{l}\mathrm{h}(\mathrm{z}=0, \mathrm{t})=-75 \mathrm{~cm} \\
\mathrm{~h}(\mathrm{z}=\mathrm{L}, \mathrm{t})=-1000 \mathrm{~cm}\end{array}$ \\
\hline $\begin{array}{l}\text { Gas phase oxygen } \\
\text { transport model }\end{array}$ & $\mathrm{O}_{2, \mathrm{~g}}(\mathrm{t}=0, \mathrm{z})=64.19 \mathrm{mg} / \mathrm{L}$ & $\begin{array}{l}\mathrm{O}_{2, \mathrm{~g}}(\mathrm{z}=0, \mathrm{t})=243.84 \mathrm{mg} / \mathrm{L} \\
\frac{\partial \mathrm{O}_{2, \mathrm{~g}}}{\partial \mathrm{z}}(\mathrm{z}=\mathrm{L}, \mathrm{t})=0\end{array}$ \\
\hline Biomass & $\begin{array}{l}\mathrm{M}(\mathrm{t}=0, \mathrm{z})=0 \mathrm{mg} / \mathrm{L} \\
\mathrm{M}_{\mathrm{S}}(\mathrm{t}=0, \mathrm{z})=0 \mathrm{mg} / \mathrm{L}\end{array}$ & $\begin{array}{l}\mathrm{M}(\mathrm{z}=0, \mathrm{t})=1.86 \mathrm{mg} / \mathrm{L} \\
\quad \frac{\partial \mathrm{M}}{\partial \mathrm{z}}(\mathrm{z}=\mathrm{L}, \mathrm{t})=0\end{array}$ \\
\hline Dissolved oxygen & $\mathrm{O}_{2}(\mathrm{t}=0, \mathrm{z})=3 \mathrm{mg} / \mathrm{L}$ & $\begin{array}{l}\mathrm{O}_{2}(\mathrm{z}=0, \mathrm{t})=11.29 \mathrm{mg} / \mathrm{L} \\
\quad \frac{\partial \mathrm{O}_{2}}{\partial \mathrm{z}}(\mathrm{z}=\mathrm{L}, \mathrm{t})=0\end{array}$ \\
\hline \multicolumn{3}{|c|}{ Aqueous phase benzene transport model } \\
\hline Case 1 & $\mathrm{C}(\mathrm{t}=0, \mathrm{z})=0 \mathrm{mg} / \mathrm{L}$ & $\begin{array}{l}\mathrm{C}(\mathrm{z}=0, \mathrm{t})=\mathrm{C}_{\mathrm{s}}=1770 \mathrm{mg} / \mathrm{L} \\
\quad \frac{\partial \mathrm{C}}{\partial \mathrm{z}}(\mathrm{z}=\mathrm{L}, \mathrm{t})=0\end{array}$ \\
\hline Case 2 & $\mathrm{C}(\mathrm{t}=0, \mathrm{z})=0 \mathrm{mg} / \mathrm{L}$ & $\begin{array}{l}\mathrm{C}(\mathrm{z}=0, \mathrm{t})=\mathrm{C}_{s} \mathrm{e}^{-\varepsilon t} \\
\frac{\partial \mathrm{C}}{\partial \mathrm{z}}(\mathrm{z}=\mathrm{L}, \mathrm{t})=0\end{array}$ \\
\hline Case 3 & $\mathrm{C}(\mathrm{t}=0, \mathrm{z})=0 \mathrm{mg} / \mathrm{L}$ & $\begin{array}{c}\left|v C-D \frac{\partial C}{\partial z}\right|_{(\mathrm{z}=0, \mathrm{t})}=0 \\
\frac{\partial \mathrm{C}}{\partial \mathrm{z}}(\mathrm{z}=\mathrm{L}, \mathrm{t})=0\end{array}$ \\
\hline
\end{tabular}

Table 2. Hydrodynamic properties and transport parameters for unsaturated zone.

\begin{tabular}{|c|c|c|c|}
\hline Parameter & Notation & Value & Reference \\
\hline Depth of unsaturated zone $(\mathrm{cm})$ & $\mathrm{L}$ & 500 & Assumed \\
\hline Total simulation time (days) & - & 10 & Assumed \\
\hline Soil type & - & Sand & \\
\hline Van Genuchten parameter $\left(\mathrm{cm}^{-1}\right)$ & $\alpha$ & 0.0335 & Mitchell and Mayer (1998) \\
\hline Van Genuchten parameter & $\beta$ & 2.0 & Mitchell and Mayer (1998) \\
\hline Van Genuchten parameter & $\eta$ & 0.5 & $1-(1 / \beta)$ \\
\hline Saturated water content & $\theta_{\mathrm{S}}$ & 0.381 & Mitchell and Mayer (1998) \\
\hline Residual water content & $\theta_{\mathrm{r}}$ & 0.102 & Mitchell and Mayer (1998) \\
\hline Saturated hydraulic conductivity $(\mathrm{cm} / \mathrm{s})$ & $\mathrm{K}_{\mathrm{s}}$ & 0.00922 & Mitchell and Mayer (1998) \\
\hline Soil bulk density (mg/L) & $\rho_{\mathrm{b}}$ & $1.6 \times 10^{6}$ & Lee et al. (2006) \\
\hline Mean particle diameter $(\mathrm{cm})$ & $d_{p}$ & 0.320 & Brusseau et al. (1991) \\
\hline Molecular diffusion coefficient $\left(\mathrm{cm}^{2} / \mathrm{h}\right)$ & $\mathrm{D}_{\mathrm{m}}$ & 0.012 & Overman (1975) \\
\hline Longitudinal dispersivity (cm) & $\lambda_{\mathrm{L}}$ & 0.5 & Lee et al. (2006) \\
\hline Diffusion coefficient of $\mathrm{O}_{2}$ in free air $\left(\mathrm{cm}^{2} / \mathrm{sec}\right)$ & $\mathrm{D}_{0}$ & 0.206 & Alfnes et al. (2004) \\
\hline $\begin{array}{l}\text { Henry's law constant for } \mathrm{O}_{2} \text { at } 10^{\circ} \mathrm{C} \\
\text { (air/water } \mathrm{mg} / \mathrm{L} \text { ) }\end{array}$ & $\mathrm{H}$ & 21.58 & Alfnes et al. (2004) \\
\hline Mass transfer coefficient $\left(\right.$ day $\left.^{-1}\right)$ & $\omega$ & 5 & Alfnes et al. (2004) \\
\hline
\end{tabular}

Table 3. Parameters used in the one-dimensional simulation for benzene transport.

\begin{tabular}{llll}
\hline Parameter & Notation & Value & \multicolumn{1}{c}{ Reference } \\
\hline Distribution coefficient of benzene $(\mathrm{l} / \mathrm{mg})$ & $\mathrm{K}_{\text {sorp }}$ & $0.506 \times 10^{-6}$ & Choi et al. $(2005)$ \\
Volatilization rate coefficient of benzene $\left(\mathrm{sec}^{-1}\right)$ & $\lambda_{\text {vol }}$ & $2.217 \times 10^{-5}$ & Choi et al. $(2005)$ \\
Maximum specific growth rate of bacteria $\left(\mathrm{min}^{-1}\right)$ & $\mu_{\mathrm{max}}$ & $4.44 \times 10^{-3}$ & Kim et al. $(2003)$ \\
Half saturation constant of benzene $(\mathrm{mg} / \mathrm{L})$ & $\mathrm{K}_{\mathrm{c}}$ & 279 & Kim et al. $(2003)$ \\
Bacterial yield coefficient & $\mathrm{Y}$ & 0.14 & Kim et al. $(2003)$ \\
Bacterial attachment rate coefficient $\left(\mathrm{min}^{-1}\right)$ & $\mathrm{K}_{\mathrm{a}}$ & $1.20 \times 10^{-3}$ & Hendry et al. $(2002)$ \\
Bacterial detachment rate coefficient $\left(\mathrm{min}^{-1}\right)$ & $\mathrm{K}_{\mathrm{d}}$ & $1.20 \times 10^{-4}$ & Hendry et al. $(2002)$ \\
Bacterial death rate coefficient $\left(\mathrm{min}^{-1}\right)$ & $\mathrm{K}_{\mathrm{dec}}$ & $1.60 \times 10^{-4}$ & Kim et al. $(2003)$ \\
Oxygen use coefficient & $\mathrm{F}$ & 2.15 & Chen et al. $(1992)$ \\
Haldane inhibition constant of benzene $(\mathrm{mg} / \mathrm{L})$ & $\mathrm{K}_{i}$ & 130 & Kim et al. $(2003)$ \\
Half-saturation constant of oxygen $(\mathrm{mg} / \mathrm{L})$ & $\mathrm{K}_{0}$ & 0.2 & Kinzelbach et al. $(1991)$
\end{tabular}


implicit, finite difference scheme with explicit linearization of $\mathrm{K}(\mathrm{h})$ and $\mathrm{C}(\mathrm{h})$ has been adopted in order to solve equation (1) (Van Dam and Feddes 2000). The resulting tri-diagonal systems of linear algebraic equations are solved using the Thomas algorithm. The unsaturated flow model is solved first to obtain the pressure head distribution in the unsaturated soil profile. Similarly, the air flow model is also solved to get the oxygen concentration in the air phase. The oxygen concentration in the air phase is used in the associated dissolved oxygen model. The obtained values of pressure head $h(z, t)$ is used to compute $\theta(z, t), \mathrm{D}(z, t)$, and $q(z, t)$, which appear in the systems describing the mass transport of benzene (equation 8), bacteria (equation 9), and dissolved oxygen (equation 11). Then, the coupled system of benzene, bacteria, and dissolved oxygen equations (equations 8-12) are solved using fully implicit finite difference scheme for the given initial and boundary conditions to get the concentration profile in the unsaturated zone. The algorithm for the integration of various modules used in the present study has been shown using a flow chart in figure 1 . The advection part, which reflects the hyperbolic nature of the given partial differential equation is discretized using first order upwind scheme, while the dispersive part, which reflects the parabolic nature of the given partial differential equation is discretized using second order central difference scheme. The vertical one-dimensional unsaturated spatial domain is divided into a finite number of discrete cells having same width $(\Delta z)$ as shown in figure 2 . For temporal discretization, the total simulation time is divided into a finite number of time intervals $(\Delta t)$. Even though the fully implicit numerical scheme is unconditionally stable, in order to precisely represent the small scale mass transfer at the soilwater interface, the spatial and temporal step sizes are selected by limiting the value of Courant number to be $<0.5$. However, variation of $\Delta z$ and $\Delta t$ does not result in significant change in the predicted concentration values. Thus the optimum values for $\Delta z$ and $\Delta t$ are taken as $0.5 \mathrm{~cm}$ and $100 \mathrm{sec}$, respectively.

\section{Results and discussions}

The present numerical scheme has been validated with analytical/numerical results, after it is checked for its consistency and stability. To examine the performance of the flow model (equation 1), numerical simulations were carried out using data from the one-dimensional numerical experiment of Phoon et al. (2007), where water infiltrates into a homogeneous soil column which is initially dry. The porous media hydraulic properties, initial and boundary conditions for this validation test are shown in table 4 . Figure 3 provides the comparison of the results obtained from present flow model with that of Phoon et al. (2007). It is observed that the model predictions are in good agreement with the reported values of pressure head.

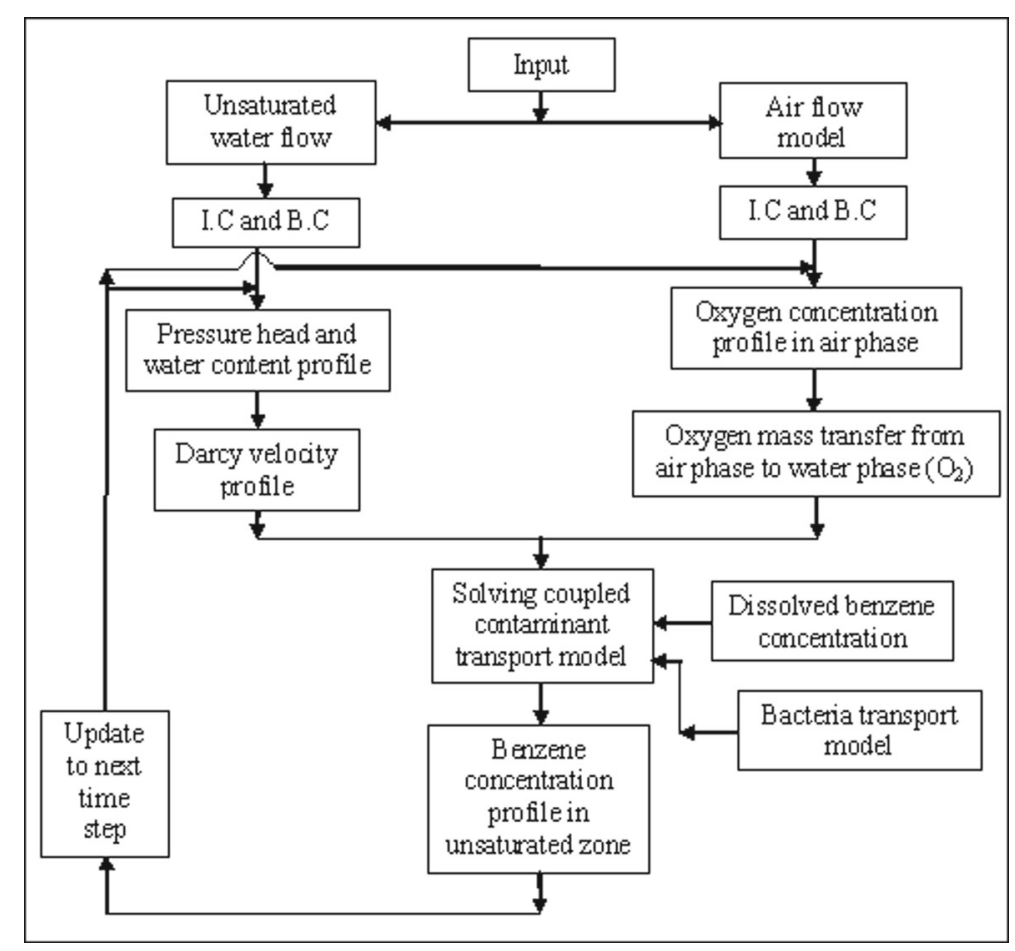

Figure 1. Schematic representation of solving of water flow, air flow, and transport of benzene in unsaturated porous media. 


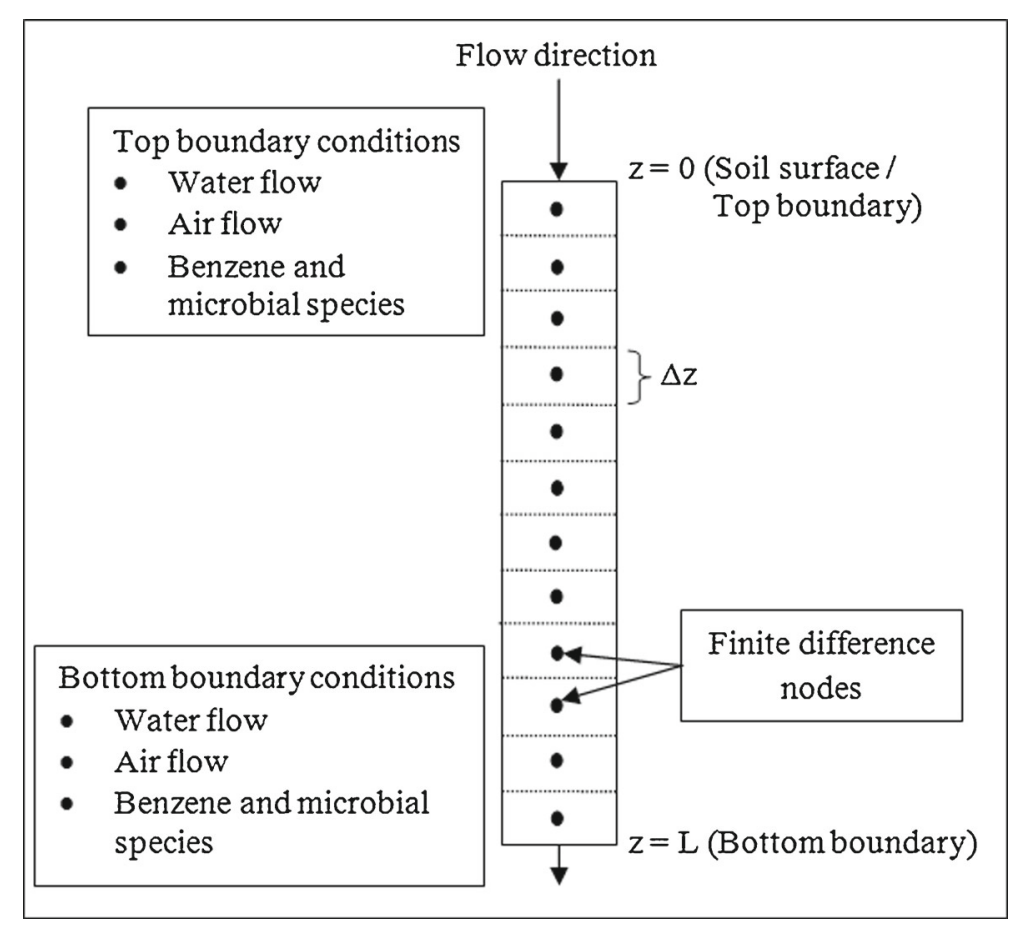

Figure 2. Graphical representation of unsaturated one-dimensional spatial domain.

Similarly, the single species contaminant transport model for an unsaturated system is validated using the data from Ojha et al. (2012) which is used to predict the virus movement. The transport model used by Ojha et al. (2012) is similar to equation (8) mentioned above except for the last term, which represents the Monod kinetic reaction. The porous media hydraulic properties, initial and boundary conditions for single species transport validation experiment are shown in table 4 . Figure 4 shows the comparison of the predicted concentration obtained by the present model with that of Ojha et al. (2012) for the simulation period of 1 and 10 days. The predicted values are in good agreement with the numerical model results by Ojha et al. (2012), as given in figure 4. Further, the model results are compared with the analytical solution for the reactive transport model with a first order reaction and the results are also in good agreement with the developed model (figure 5).

Since this study considered the transport of dissolved benzene, bacteria, and dissolved oxygen, the validation of multi-species transport in unsaturated zone is required to be validated in order to check the reliability of the coupled system of equations. Since there is no experimental study or analytical solution considering all the species (benzene, microbe and dissolved oxygen) in an unsaturated soil, simulations were carried out for multi-species data with first order rate kinetics given by Bailey et al. (2013). It is observed from figure 6 that the simulated concentrations by the present combined model (without Monod kinetic reaction) are in good agreement with Bailey et al. (2013).

\subsection{Case 1: Constant continuous source}

In order to understand the immediate effects of a NAPL spill in determining the long term fate of toxic compounds in the subsurface, the present numerical model is employed for predicting the dissolved benzene plume originating from the NAPL pool at the soil surface and continuously migrating downwards. Incorporating the effects of volatilization, sorption, and biodegradation, simulation is carried out for the first 100 days to understand the significance of each of these reactions on the overall fate of benzene.

Figure 7 provides the depthwise distribution of benzene, bacteria, and dissolved oxygen at the end of 10 days of the spill event, indicating the significance of bio-chemical reactions in the subsurface. It is observed from figure 7 (a) that benzene has reached its maximum solubility near the boundary due to equilibrium dissolution, and is found to be decreasing with depth in accordance with the pressure head and moisture distribution. The effect of retardation is considered in the present model to incorporate the significance of soil-water partitioning of the contaminant. It is observed that, after a period of 10 days, benzene concentration has reached a depth of $150 \mathrm{~cm}$ where the concentration is very small due to the possible dilution and dispersion effects. It is interesting to note that the effect of aerobic bacteria in degrading the 
Table 4. Parameter used for model validations.

\begin{tabular}{|c|c|}
\hline Parameter & Value \\
\hline \multicolumn{2}{|l|}{ Water flow model (Phoon et al. 2007) } \\
\hline Element size $(\mathrm{m})$ & 0.0025 \\
\hline Time step (sec) & 30 \\
\hline Total simulation time (sec) & 46800 \\
\hline Van Genuchten parameter $(\alpha)\left(\mathrm{m}^{-1}\right)$ & 1 \\
\hline Van Genuchten parameter $(\beta)$ & 1.53 \\
\hline Van Genuchten parameter $(\eta)$ & 0.3464 \\
\hline Saturated water content & 0.363 \\
\hline Residual water content & 0.186 \\
\hline Saturated conductivity (m/s) & $1 \times 10^{-6}$ \\
\hline Top boundary (m) & 0 \\
\hline Bottom boundary (m) & -8 \\
\hline Initial condition $(\mathrm{m})$ & -8 \\
\hline \multicolumn{2}{|l|}{ Contaminant transport (Ojha et al. 2012) } \\
\hline Element size $(\mathrm{cm})$ & 1 \\
\hline Time step (sec) & 20 \\
\hline Van Genuchten parameter $(\alpha)\left(\mathrm{cm}^{-1}\right)$ & 0.0335 \\
\hline Van Genuchten parameter $(\beta)$ & 2 \\
\hline Van Genuchten parameter $(\eta)$ & 0.5 \\
\hline Saturated water content & 0.368 \\
\hline Residual water content & 0.102 \\
\hline Saturated conductivity $(\mathrm{cm} / \mathrm{s})$ & 0.0092 \\
\hline Top boundary (cm) & -75 \\
\hline Bottom boundary $(\mathrm{cm})$ & -1000 \\
\hline Initial condition (cm) & -1000 \\
\hline Bulk density of soil $\left(\mathrm{g} / \mathrm{cm}^{3}\right)$ & 1.11 \\
\hline Distribution coefficient (ml/g) & 0.02 \\
\hline Inactivation coefficient $\left(\right.$ day $\left.^{-1}\right)$ & 0.58 \\
\hline Initial concentration (mg/L) & 0 \\
\hline Top boundary condition (mg/L) & 1 \\
\hline \multicolumn{2}{|c|}{ Multi-species transport model (Bailey et al. 2013) } \\
\hline Element size $(\mathrm{cm})$ & 1 \\
\hline Van Genuchten parameter $(\alpha)\left(\mathrm{m}^{-1}\right)$ & 14.5 \\
\hline Van Genuchten parameter $(\beta)$ & 3.1 \\
\hline Van Genuchten parameter $(\eta)$ & 0.677 \\
\hline Saturated water content & 0.4 \\
\hline Residual water content & 0.1 \\
\hline Saturated conductivity $(\mathrm{m} / \mathrm{d})$ & 0.5 \\
\hline Longitudinal dispersivity (m) & 0.04 \\
\hline Initial concentration - all species (mg/L) & 0 \\
\hline Top boundary - species 1 (mg/L) & 50 \\
\hline Top boundary - species $2(\mathrm{mg} / \mathrm{L})$ & 0 \\
\hline Top boundary - species 3 (mg/L) & 10 \\
\hline Reaction rate for species 1 (per day) & 0.12 \\
\hline Reaction rate for species 2 (per day) & 0.048 \\
\hline Reaction rate for species 3 (per day) & 0.012 \\
\hline
\end{tabular}

concentration is significant up to a depth of 70 $\mathrm{cm}$. For example, the benzene concentration is reduced to $1730 \mathrm{mg} / \mathrm{L}$ in the presence of highly efficient microbial culture $(100 \mathrm{mg} / \mathrm{L})$ (figure $7 \mathrm{a})$. It is understood that the high concentration values of benzene and bacteria represent highly growth inhibiting conditions, which are incorporated by the Haldane kinetic term. This reduction in concentration is confirmed by the bacterial concentration profile (figure $7 \mathrm{~b}$ ) and the corresponding dissolved oxygen (figure 7c) consumption by the bacteria. It is further attributed from figure 7 (b and c) that the considerable reduction in DO during high microbial concentration (at $100 \mathrm{mg} / \mathrm{L}$ of bacteria) may decrease the biodegradation rate (figure 8). It is observed from figure 8 that biodegradation rate is highest $(\approx 0.05 /$ day $)$ when the microbial concentrations are 1 and $25 \mathrm{mg} / \mathrm{L}$ respectively, whereas it is reduced to $0.0425 /$ day and 0.035 /day for the microbial concentrations of 50 and $100 \mathrm{mg} / \mathrm{L}$, respectively. It is also observed that dissolved oxygen concentration is decreasing significantly when the microbial concentration is increased. However, it is to be noted that even though highly aerobic conditions are present near the surface during low microbial concentration, continuous addition of benzene is inhibiting the bacterial growth, hence the variation for the dissolved benzene plume is limited near the soil surface. Thus it can be concluded from figures 7 and 8 that the effect of biodegradation is significant for understanding the fate and transport of dissolved benzene in the subsurface. Hence, early removal of free phase benzene from the source is highly beneficial to stop further contamination downwards.

Figure 9 provides the variation in the dissolved benzene concentration along the depth for different volatilization rates after a simulation period of 100 days. It is observed from figure 9 that for the selected volatilization rate $\left(\lambda_{\mathrm{vol}}=2.217 \times 10^{-5}\right.$ $\left.\mathrm{sec}^{-1}\right)$, there is a sharp decrease in the benzene concentration for first $50 \mathrm{~cm}$ depth, whereas the decrease in the volatilization rate resulted in wide distribution of the concentration profile up to a depth of $200 \mathrm{~cm}$. The model is found to be highly sensitive towards the volatilization rate coefficient and the resultant effect is more significant at the shallow depth, indicating a higher removal rate of benzene from dissolved phase. Since volatilization is an inevitable phenomenon happening in the unsaturated zone and benzene is more susceptible to partitioning to the vapour phase, the estimation of volatilization rate is critical in representing the real field scenario of vapour migration as well as for deciding remediation such as soil vapour extraction for removing the free vapour phase.

\subsection{Case 2: Continuous source with first order decay}

Since the spilled benzene is subjected to rapid mass losses such as source volatilization or irreversible sorption, it is important to include the changing boundary condition for the present numerical model. It is assumed that the decrease in the source 


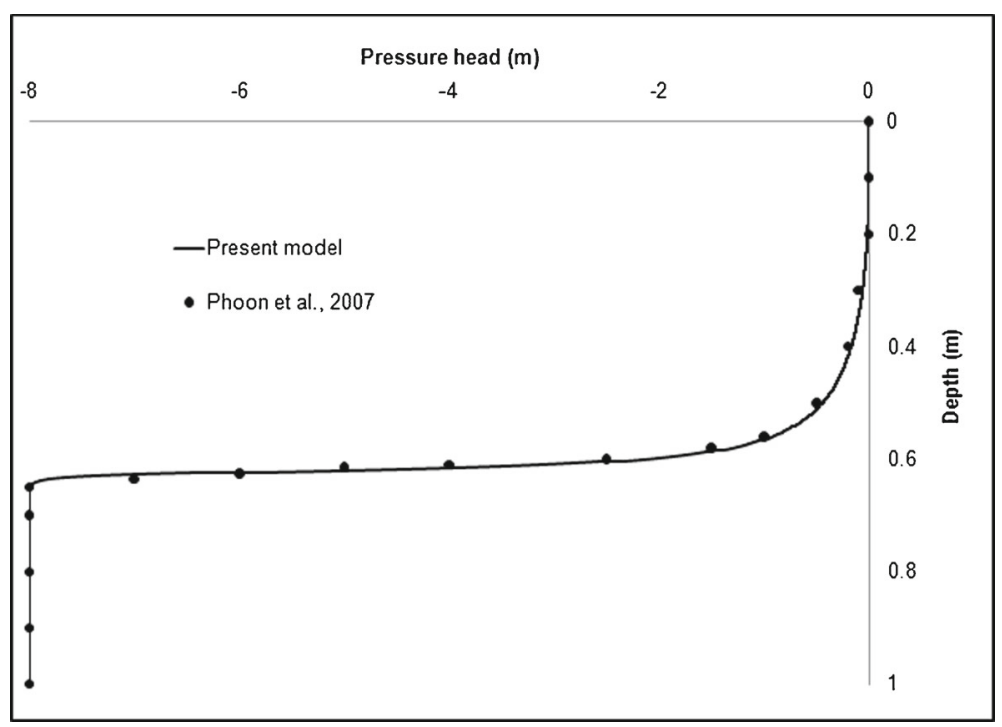

Figure 3. Validation of present model for flow in unsaturated soil after $86400 \mathrm{sec}$, with $\theta_{r}=0.186, \theta_{s}=0.363, \alpha=1.0 \mathrm{~m}^{-1}$, $\beta=1.53$, and $K_{s}=1.0 \times 10^{-6} \mathrm{~m} / \mathrm{sec}$.

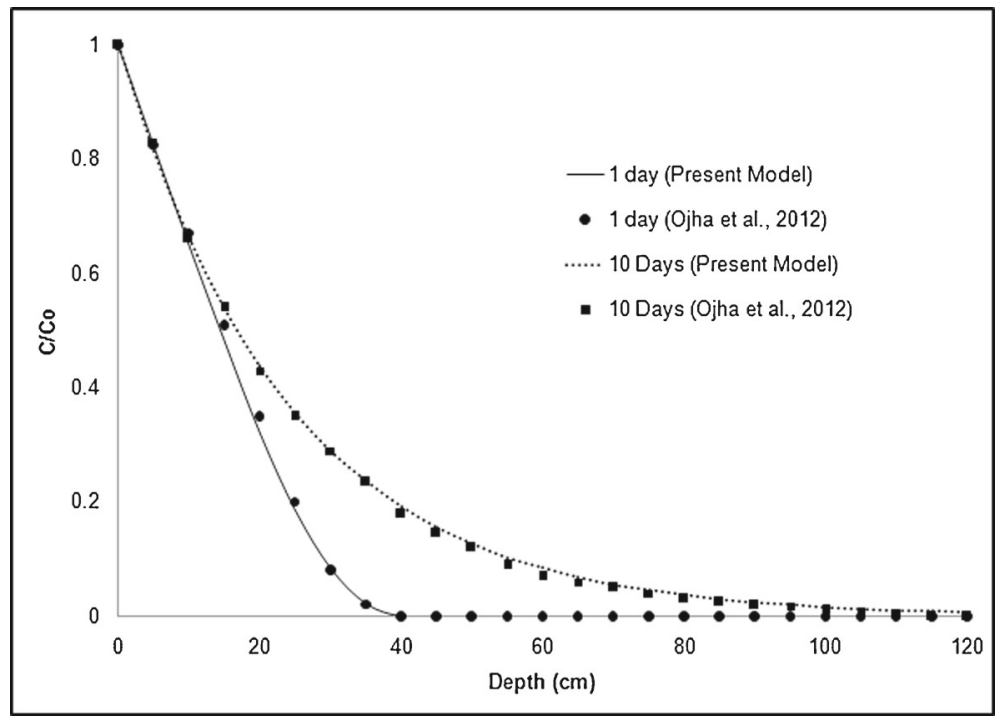

Figure 4. Validation of present contaminant transport model with single species in unsaturated soil with $\theta_{r}=0.102$, $\theta_{s}=0.381, \alpha=0.0335 \mathrm{~cm}^{-1}, \beta=2$, and $K_{s}=0.00922 \mathrm{~cm} / \mathrm{s}$.

strength is directly affecting the subsequent mass transfer and transport processes for the dissolved benzene plume (refer table 1 ).

Figure 10 provides the depth-wise profile of benzene concentration for the decaying source at different time intervals with and without the presence of bacteria. It is observed that the concentration near the top boundary is considerably decreased with respect to time because of the decaying source at the surface. Also the concentration reached a depth of about $40 \mathrm{~cm}$ at the end of the first day irrespective of the bacterial degradation, which can be attributed to the inhibition effect at high concentration during initial period. However, it is to be noted that the presence of bacteria is significant after a depth of $20 \mathrm{~cm}$ at the end of 100 days, resulting in lower concentration at higher depths. The concentration profile at the end of 500 days is also found to be restricted within the first $40 \mathrm{~cm}$ because of the reduced source strength from the top boundary. At the end of 500 days, biodegradation is responsible for the fast decrease in concentration within a depth of $30 \mathrm{~cm}$. Hence, it can be concluded that incorporating source decay is significantly affecting the subsurface leaching of the contaminant especially in presence of biodegradation. It is recommended that bioremediation be effective at lower depths when the contaminant source is 


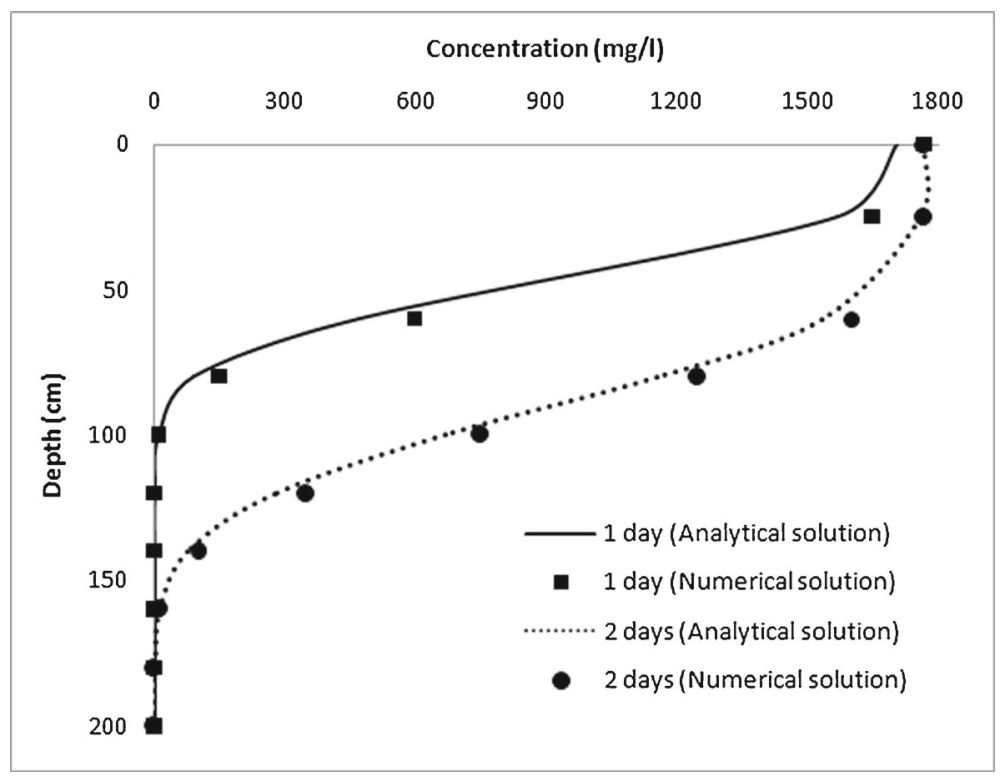

Figure 5. Validation of contaminant transport model with analytical solution $\left[v=5.0 \times 10^{-4} \mathrm{~cm} / \mathrm{sec}, \lambda_{L}=0.5 \mathrm{~cm}\right.$, $\left.C_{0}=1770 \mathrm{mg} / \mathrm{L}\right]$.

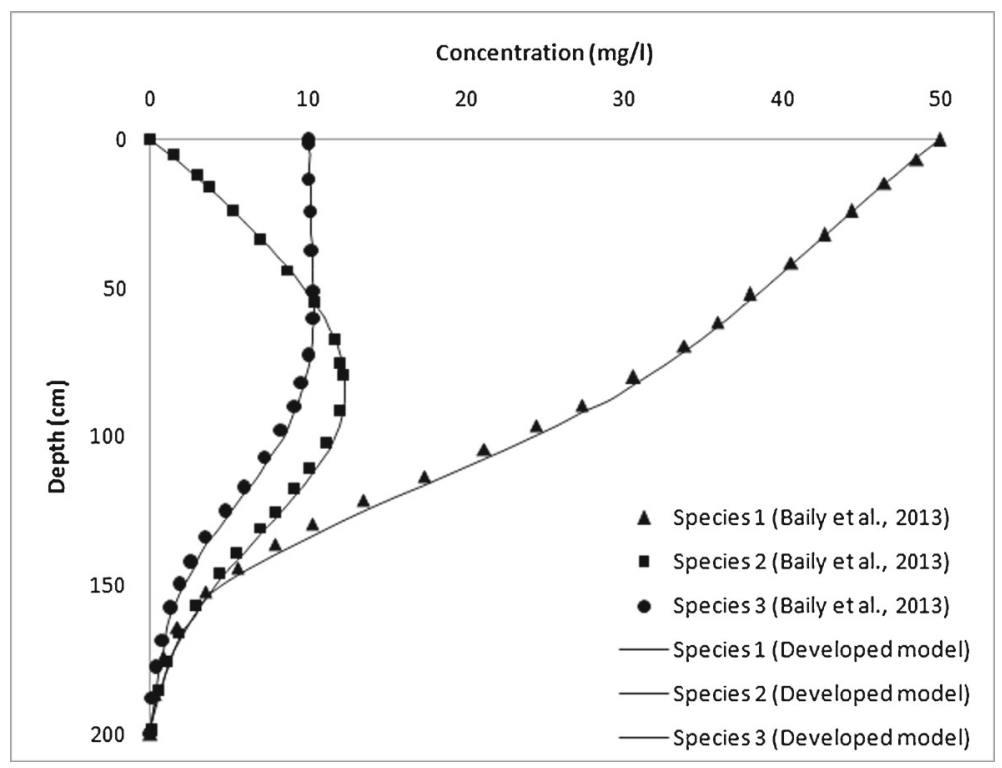

Figure 6. Validation of multi-species contaminant transport model in unsaturated soil.

restrained from inducing the inhibitory effects on the bacteria.

Figure 11 provides temporal variation of benzene concentration at three different depths with and without bacteria. It is observed from figure 11 that, even though the reduction in concentration is more at $10 \mathrm{~cm}$ depth from soil surface compared with deeper zone, there is significant concentration at shallow depth even after a period of 500 days. Also in the presence of bacteria, the concentration is found to be decreasing fast during the initial period of time, whereas the variation becomes insignificant when it reaches asymptotic region. This can be explained by the enhancement to the dissolution of contaminant in presence of bacteria by the increase in the concentration gradient, which is actually depleting with the reduction in the source strength.

Figure 12 provides the temporal variation of benzene concentration for comparing the two distinct assumptions for the top boundary condition. It is observed from figure 12 that the impact of constant continuous source assumption is significantly influencing the concentration profile at shallow depth, resulting in a uniform distribution throughout the simulation period. It is important to note that in order to achieve significant concentration reduction at smaller depths, much of the source mass in the 

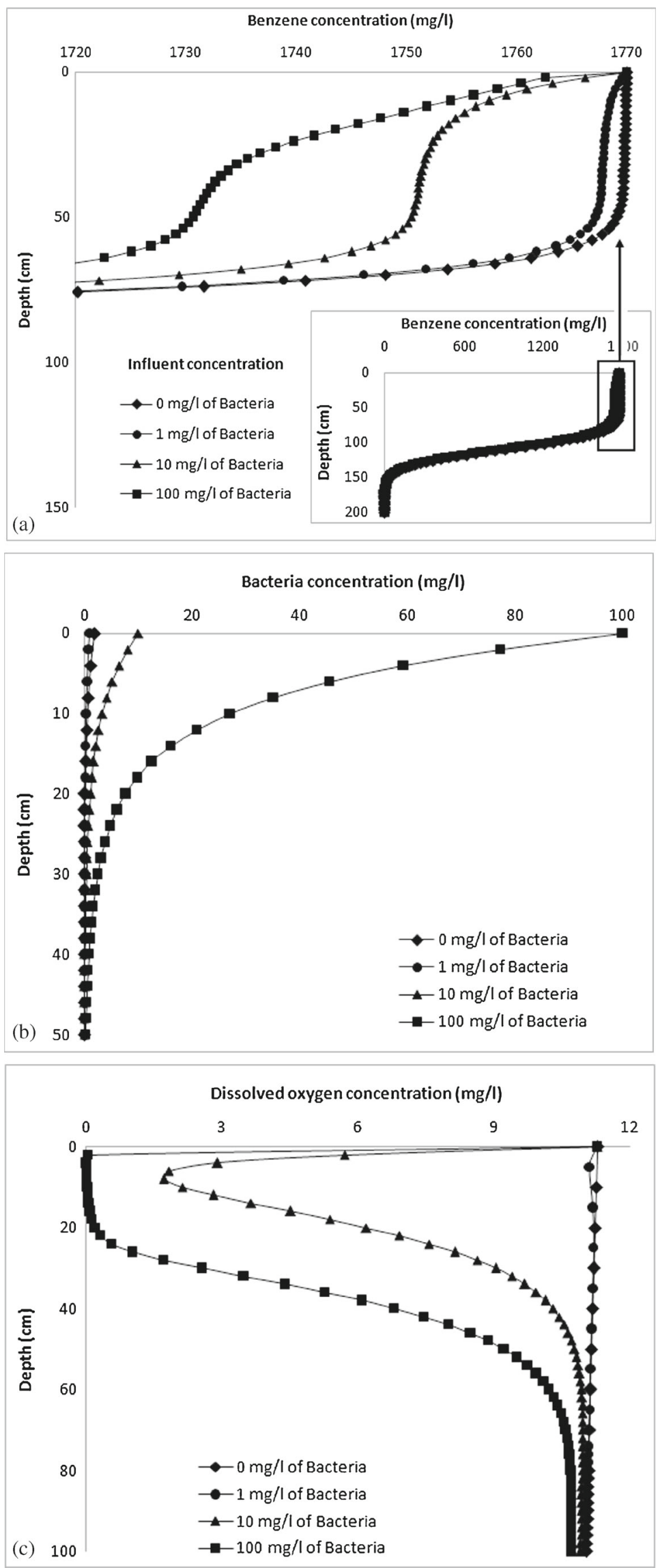

Figure 7. Simulated concentration profile of (a) benzene, (b) bacteria, and (c) dissolved oxygen after 10 days for constant continuous source (refer tables 2 and 3 for other data). 


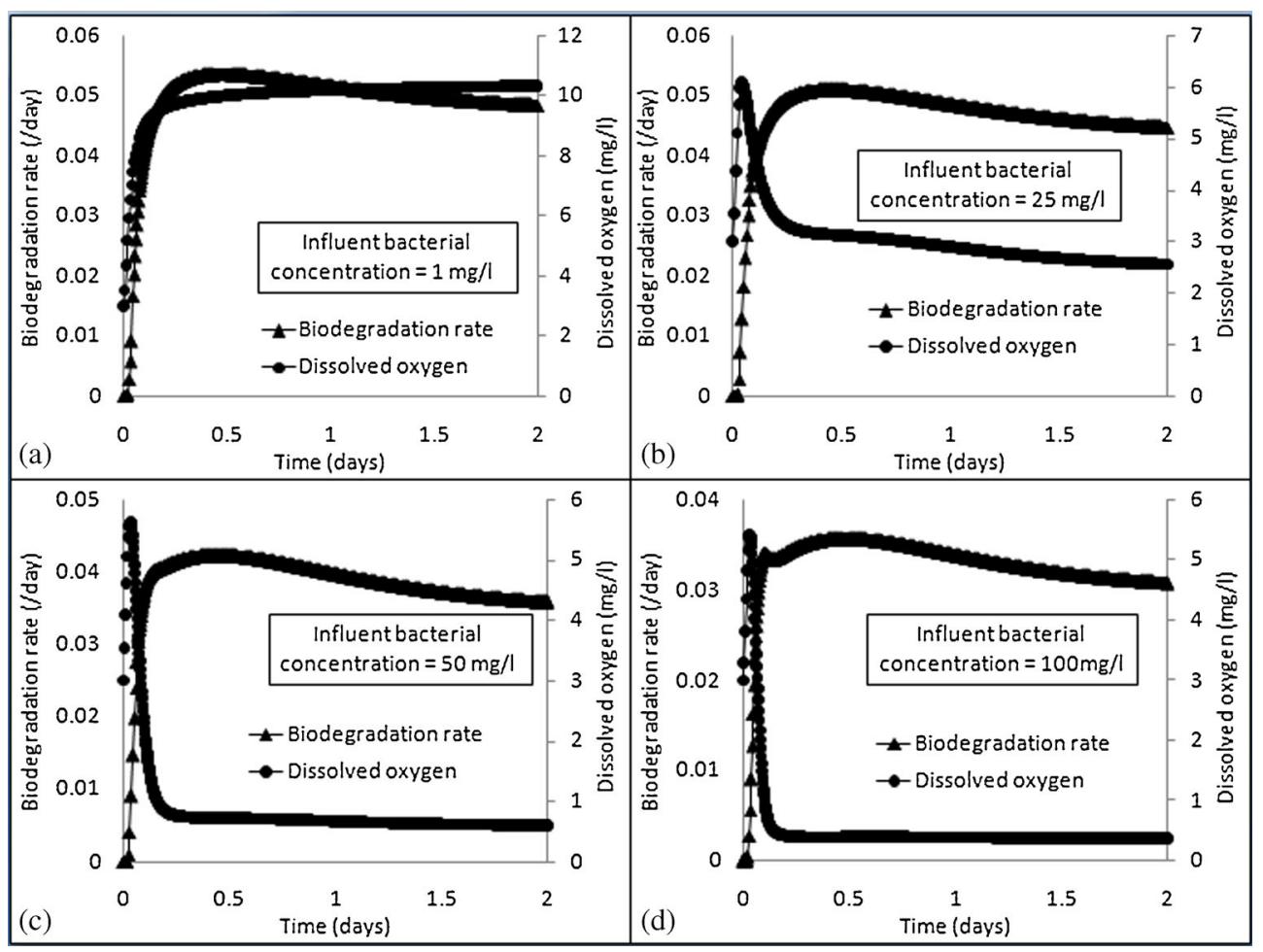

Figure 8. Variation of biodegradation rate with dissolved oxygen at $10 \mathrm{~cm}$ depth from soil surface for influent bacteria concentration of (a) $1 \mathrm{mg} / \mathrm{L}$, (b) $25 \mathrm{mg} / \mathrm{L}$, (c) $50 \mathrm{mg} / \mathrm{L}$, and (d) $100 \mathrm{mg} / \mathrm{L}$.

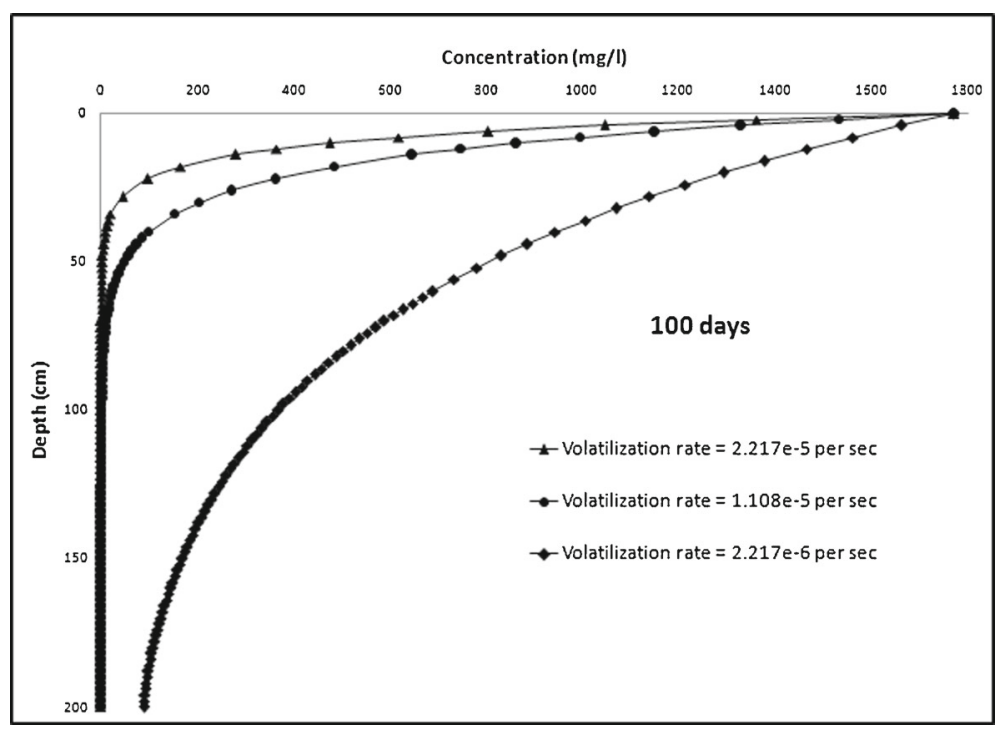

Figure 9. Sensitivity analysis of benzene concentration for volatilization rate after 100 days of simulation under constant continuous source (refer tables 2 and 3 for other data).

pure phase has to be removed by flushing or venting. Predictions by the source decay model give significant reduction within the simulated period, even though there is an extended tailing. The concentration distribution in the vertical profile shows that reduction is mostly happening in the shallow depth compared to the deeper zone indicated by the respective peak concentrations of 900,30 and 5 $\mathrm{mg} / \mathrm{L}$ for 10, 30 and $50 \mathrm{~cm}$ depths. Hence, it can be concluded that significant reduction in the source zone is achieved for the present scenario under the prevailing assumptions.

\subsection{Case 3: Rate-limited dissolution from entrapped soil pores}

The third scenario represents the distributed NAPL source as being entrapped in the soil pores, 


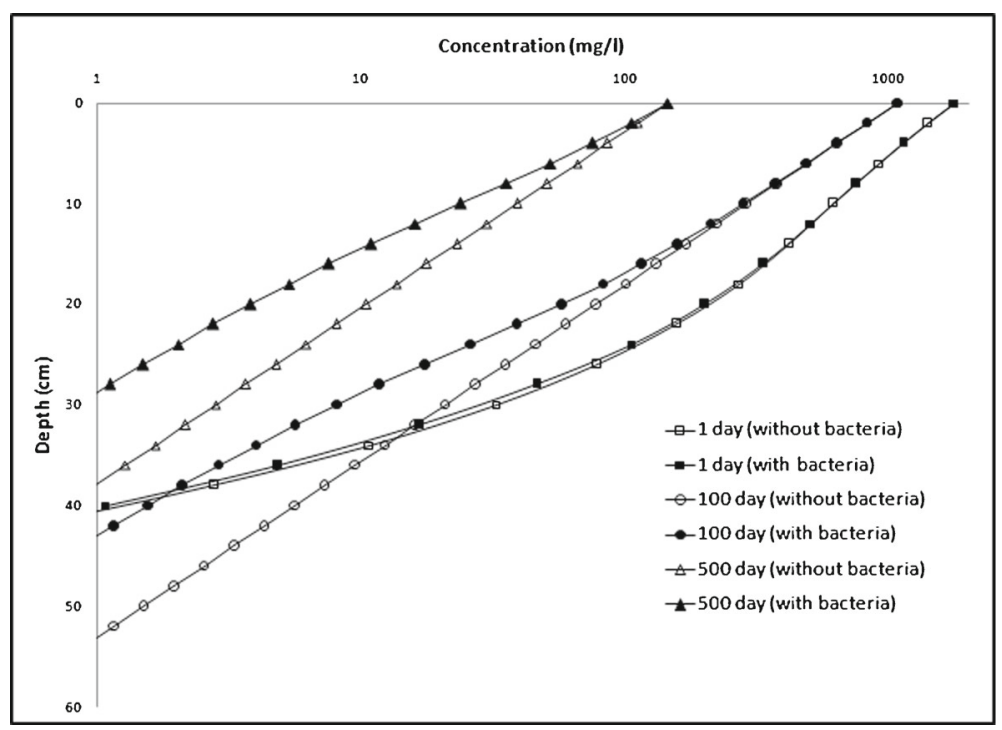

Figure 10. Concentration profile of benzene in unsaturated zone for decaying source (refer tables 2 and 3 for other data).

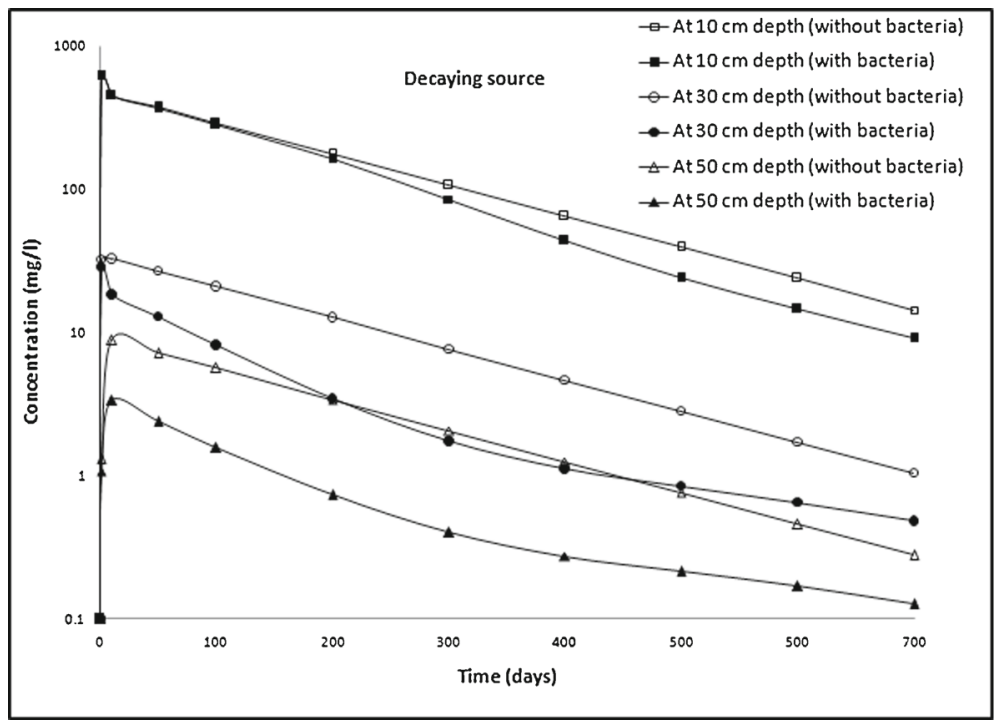

Figure 11. Temporal variation of benzene concentration in unsaturated zone for decaying source (refer tables 2 and 3 for other data).

which is causing rate-limited dissolution and hence, extended contamination of the aquifer. At this stage, most of the free phase mass has been depleted, no trace of oil phase is found separately, but the entrapped NAPL at residual saturation is still active to contribute further contamination to the flowing water by dissolution. Since the contaminant in the non-aqueous phase is present at different residual saturations, it can contribute more dissolved concentration into the infiltrating moisture, creating a non-point long term source of contamination. The present study focuses on the temporal distribution of benzene at different initial residual saturation conditions considering the coupled effect of various mass transfer processes.
Figure 13 provides temporal distribution of benzene at different depths where the volumetric residual saturation is $3 \%$, considering the influence of major mass transfer processes such as volatilization and biodegradation from the aqueous phase. In order to understand the significance of mass transfer limited conditions, the resultant benzene concentration profile is compared here with and without these mass transfer processes. It is observed from figure 13(a) that benzene concentration follows a typical dissolution breakthrough profile showing reduction in peak concentration during initial time period and extended tailing at higher time, which is more significant at shallow depth. It is also observed that there is significant 


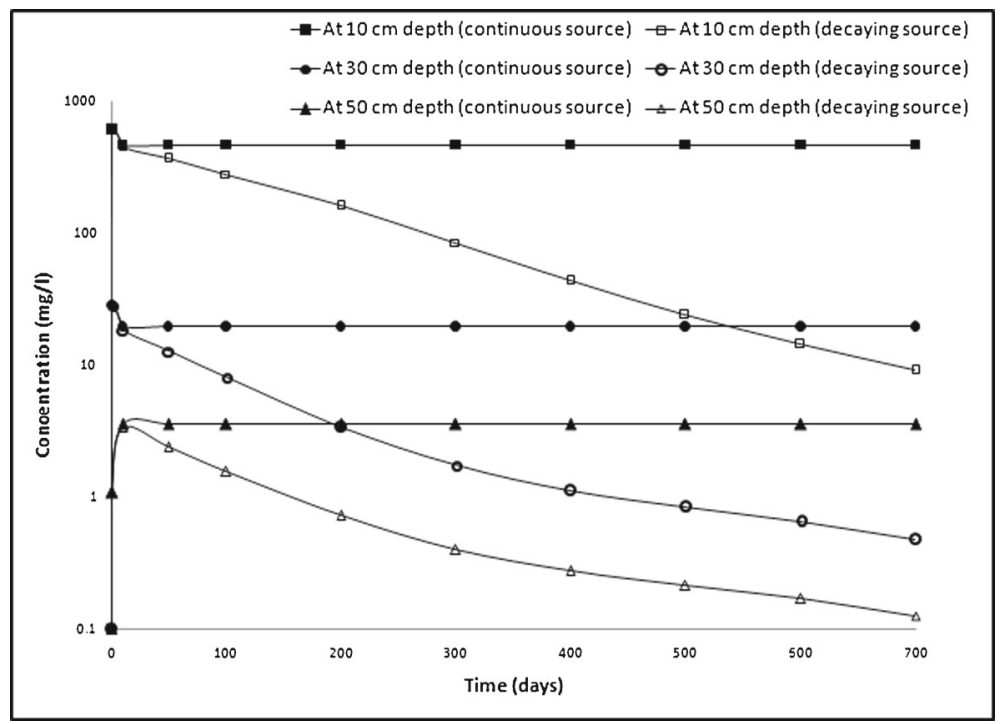

Figure 12. Temporal variation of benzene in unsaturated zone for continuous and decaying source (refer tables 2 and 3 for other data).
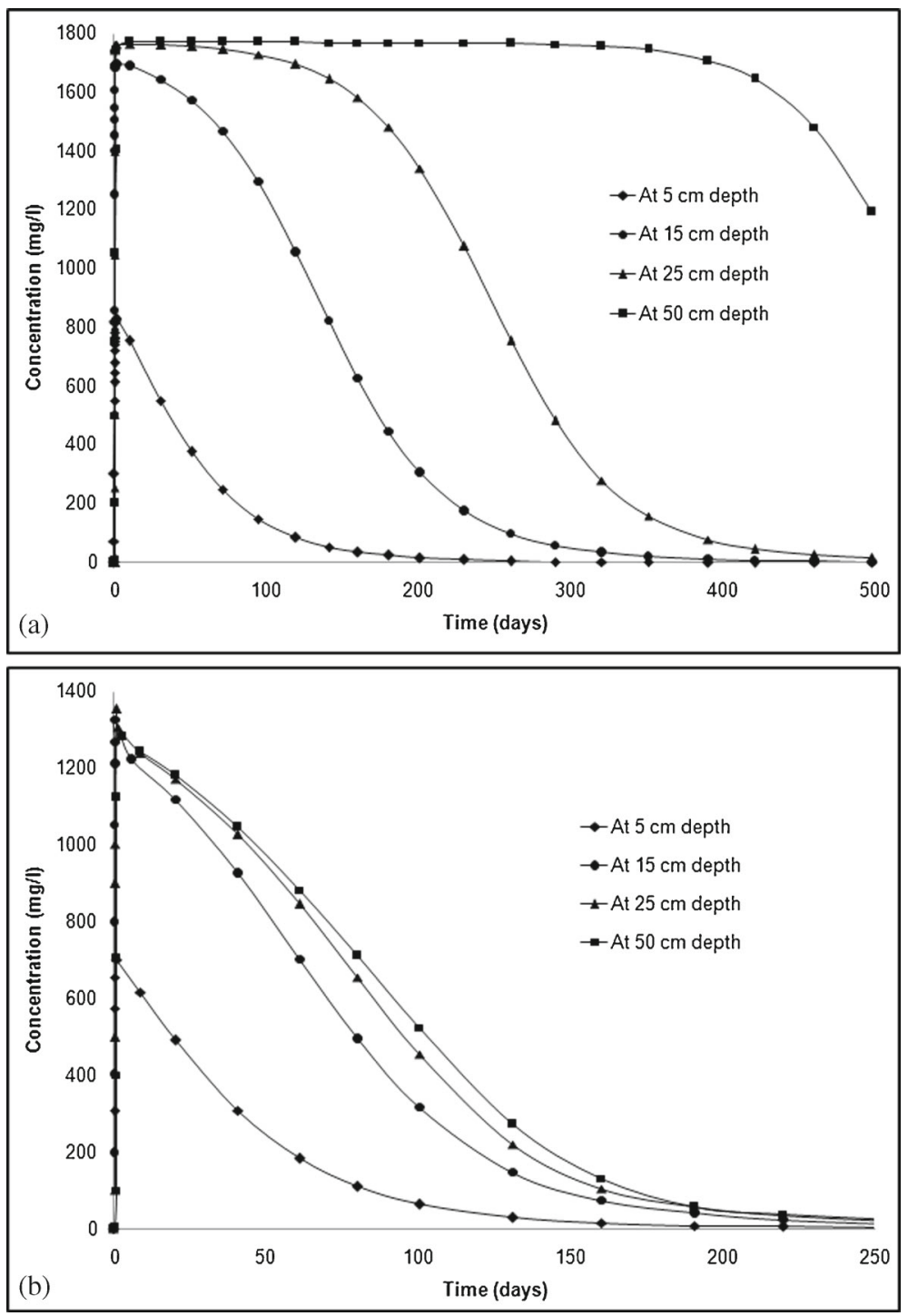

Figure 13. Temporal variation of benzene concentration for (a) only transport and (b) transport, volatilization and biodegradation at $3 \%$ residual saturation (refer tables 2 and 3 for other data). 

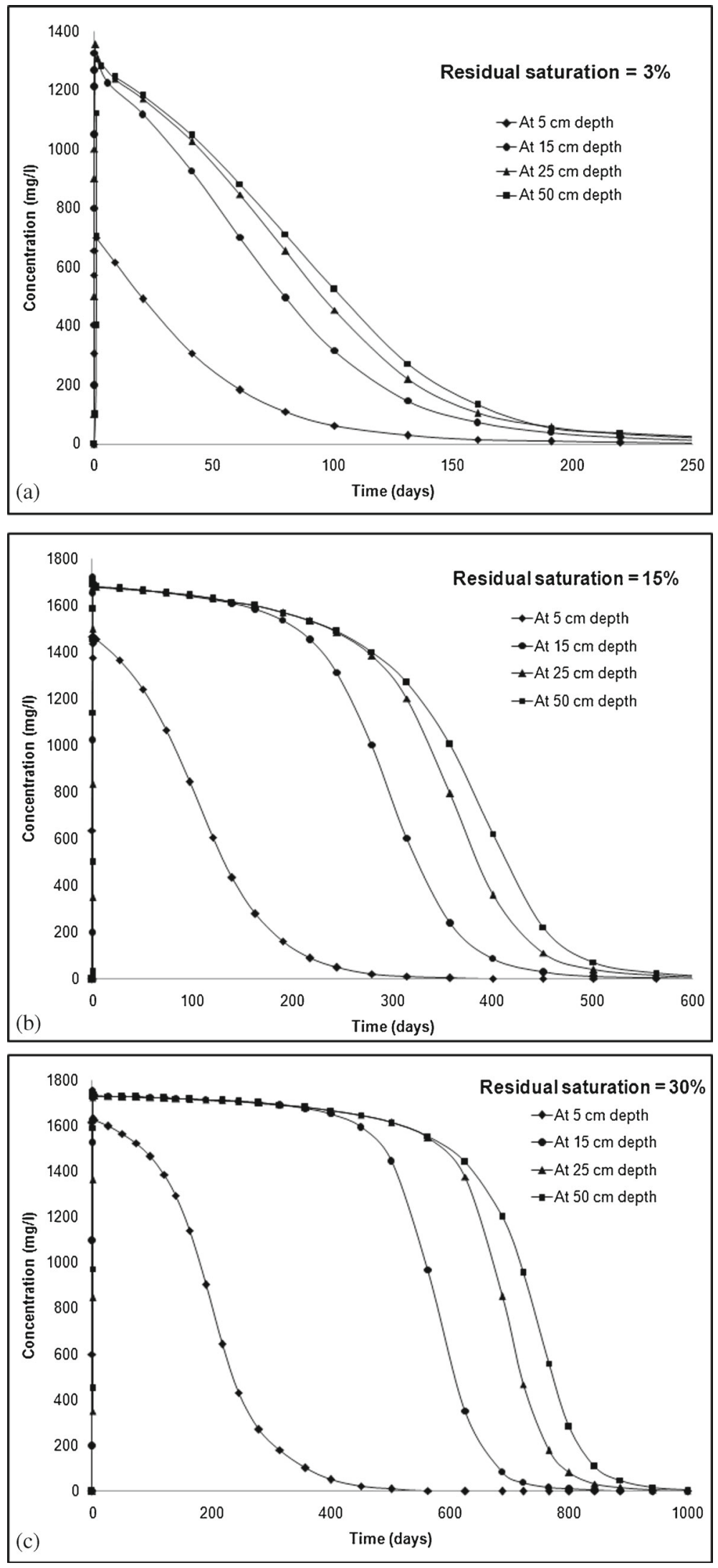

Figure 14. Temporal variation of benzene concentration for (a) 3\%, (b) 15\%, and (c) $30 \%$ residual saturation (refer tables 2 and 3 for other data). 
accumulation of dissolved mass at deeper zone due to the mass transferred from the shallow depth. Figure 13(b) represents the combined effect of rate-limited dissolution, volatilization, and biodegradation for source strength of $3 \%$. The peak concentration is significantly reduced in this case (approximately 25\%) showing the combined effect of rate-limited dissolution, volatilization and biodegradation. Also the complete mass removal from the residual source is achieved within 250 days for this case. It is interesting to note that by incorporating the volatilization, and biodegradation reactions, there is significant reduction in benzene concentration even at higher depth $(50 \mathrm{~cm})$. Since the first order equation of volatilization results in reducing the concentration from the aqueous phase which increases the concentration gradient, dissolution mass transfer rate is observed to be higher during the initial time period even though it is not able to achieve the maximum solubility concentration.

Figure 14 represents the influence of initial residual source strength on the concentration elution of benzene for three selected values of initial residual saturation as 3\%,15\% and 30\%, respectively. It is observed from figure 14 that, as the initial residual saturation is decreased from $30 \%$ to $3 \%$, the breakthrough curve converges to lower time period. At a depth of $5 \mathrm{~cm}$, peak concentration of dissolved benzene decreased from 1620 to 700 $\mathrm{mg} / \mathrm{L}$ when the residual saturation is decreased from $30 \%$ to $3 \%$. Similarly, the peak concentration is observed to be lower than the maximum solubility limit when initial residual saturation is $3 \%$, whereas the peak is observed to reach the solubility value for higher depths $(>15 \mathrm{~cm})$ when the initial residual saturation values are $15 \%$ and $30 \%$. It is also observed that the developed model is able to predict the effect of accumulated mass at higher depths indicated by high concentration and delayed breakthrough when the residual saturation values are higher. Since there is no further source addition, complete removal of dissolved phase concentration is possible within a smaller period from the shallow depths compared to the deeper zone. It is important to note that for higher values of residual saturation, more mass is entrapped in soil pores, hence more flushing is required to remove the source, especially from deeper zones. Since there is every possibility of seasonal fluctuation of water table creating large capillary zone, it can act as buffer zone for the contaminant at residual saturation to get into the water bearing stratum of the aquifer. Hence, it is critical to predict the volumetric saturation of NAPL contaminant within the unsaturated zone and time required for complete removal in order to assess the associated risk for groundwater contamination.

\section{Conclusions}

In this study, a numerical model has been developed to describe the fate and transport of benzene in an unsaturated porous medium following a surface spill, under the influence of various physical and bio-chemical reactions. The coupled system of moisture flow, air flow and corresponding transport equations are modelled by using implicit finite difference scheme in a one-dimensional domain. This study effectively considers volatilization, dissolution, sorption and microbial degradation of benzene in the unsaturated subsurface for constant continuous source, decaying source as well as for residual source. However, the assumption made in this study can be further modified by taking into account the kinetic mass transfer, which is favoured by realistic field/experimental data. The following conclusions have been arrived from the present study.

- The immediate fate of infiltrating benzene plume is well characterized by considering the spill as a constant continuous source and incorporating all possible mass transfer mechanisms. The consideration of biodegradation significantly reduced the reach of benzene plume to larger depths. However, the reduction in dissolved oxygen during high microbial activity (at $100 \mathrm{mg} / \mathrm{L}$ of bacteria) resulted in reduced biodegradation rate. Even though highly aerobic conditions are present near the surface during low microbial concentration, continuous addition of benzene is found to be inhibiting the bacterial growth, hence the variation of the dissolved benzene is limited near the soil surface. Similarly, volatilization is a significant mass transfer mechanism for the benzene in the unsaturated zone, especially at shallow depths.

- It is observed that the decrease in the source strength is directly affecting the subsequent mass transfer and transport processes for the dissolved benzene plume. By incorporating source decay, there is significant reduction in the contaminant concentration at lower depths $(<40 \mathrm{~cm})$. The concentration distribution in the vertical profile shows that reduction is mostly happening in the shallow depth compared to the deeper zone indicated by the respective peak concentrations of 900, 30, and $5 \mathrm{mg} / \mathrm{L}$ for 10,30 and $50 \mathrm{~cm}$ depths. In the presence of bacteria, the concentration is found to be decreasing fast during the initial period of time, whereas the variation becomes insignificant when it reaches asymptotic region.

- In the case of residual source of contaminant, the dissolution mass transfer became the ratelimiting step, and benzene concentration profile resulted in reduction in peak concentration 
(approximately 25\%) during initial time period and extended tailing at higher time, which is more significant at shallow depth. By incorporating the volatilization and biodegradation reactions, there is significant reduction in benzene concentration at a depth of $50 \mathrm{~cm}$ after 250,600 , and 1000 days for the values of initial residual saturation of $3 \%, 15 \%$ and $30 \%$, respectively.

The present study focuses on the significance of spill source history for assisting suitable remediation strategy by addressing the surface spill problem at different time scales of spill evolution. Considering the necessity of active remediation strategy for the site management plan, these results can be beneficial in the betterment of the risk assessment based on the estimates of associated model parameters.

\section{Acknowledgements}

Authors would like to thank the reviewers and Associate Editor of the Journal of Earth System Science for the valuable comments and suggestions to improve the quality of the manuscript.

\section{References}

Alfnes E, Breedveld G D, Kinzelbach W and Aagaard P 2004 Investigation of hydrogeologic processes in a dipping layer structure 2. Transport and biodegradation of organics; J. Contam. Hydrol. 69 173-194.

Antonopoulos V Z 2006 Water movement and heat transfer simulations in a soil under Ryegrass; Biosys. Engg. 95 127-138.

Baedecker M J, Cozzarelli I M, Siegel D I, Bennett P C and Eganhouse R P 1993 Crude oil in a shallow sand and gravel aquifer - III. Biogeochemical reactions and mass balance modeling in anoxic groundwater; Appl. Geochem. 8(6) 569-586.

Baedecker M J, Eganhouse R P, Bekins B A and Delin G N 2011 Loss of volatile hydrocarbons from an LNAPL oil source; J. Contam. Hydrol. 126 140-152.

Baek D S, Kim S B and Kim D J 2003 Irreversible sorption of benzene in sandy aquifer materials; Hydrol. Process. 17 1239-1251.

Bailey R T, Morway E D, Niswonger R G and Gates T K 2013 Modeling variable saturated multi-species reactive groundwater solute transport with MODFLOW-UZF and RT3D; Ground Water 51(5) 752-761.

Berlin M, Suresh Kumar G and Nambi I M 2013 Numerical modelling on fate and transport of nitrate in an unsaturated system under non-isothermal condition; Euro. J. Environ. Civil Engg. 17(5) 350-373.

Berlin M, Suresh Kumar G and Nambi I M 2014a Numerical modeling on transport of nitrogen from wastewater and fertilizer applied on paddy fields; Ecol. Model. 278 85-99.

Berlin M, Suresh Kumar G and Nambi I M 2014b Numerical modeling of biological clogging on transport of nitrate in an unsaturated porous media; Environ. Earth Sci., doi: 10.1007/s12665-014-3612-z.
Berlin M, Suresh Kumar G and Nambi I M 2014c Numerical modeling on the effect of dissolved oxygen on nitrogen transformation and transport in an unsaturated porous system; Environ. Model. Assess. 19(4) 283-299.

Broholm K, Feenstra S and Cherry J A 1999 Solvent release into a sandy aquifer. 1. Overview of source distribution and dissolution behaviour; Environ. Sci. Technol. 33 681-690.

Brooks R J and Corey A T 1964 Hydraulic properties of porous media; Hydrol. Pap. 3, Colorado State Univ., Fort Collins.

Brusseau M L, Larsen T and Christensen T H 1991 Ratelimited sorption and non-equilibrium transport of organic chemicals in low organic carbon aquifer materials; Water Resour. Res. 27 1137-1145.

Burdine N T 1953 Relative permeability calculation from pore size distribution data; Trans. Am. Inst. Min. Eng. 198 71-78.

Celia M A, Bouloutas E T and Zarba R L 1990 A general mass-conservative numerical solution for the unsaturated flow equation; Water Resour. Res. 26 1483-1496.

Chen Y M, Abriola L M, Alvarez P J, Anid P J and Vogel T M 1992 Modeling transport and biodegradation of benzene and toluene in sandy aquifer material: Comparisons with experimental measurements; Water Resourc. Res. 28(7) 1833-1847.

Chiang C Y, Salanitro J P, Chai E Y, Colthart J D and Klein C L 1989 Aerobic biodegradation of benzene, toluene, and xylene in a sandy aquifer - Data analysis and computer modelling; Ground Water 27(6) 823-834.

Choi J W, Kim S B, Ha H C and Kim D J 2005 Analysis of benzene transport in a two-dimensional aquifer model; Hydrol. Process. 19 2481-2489.

Choi N C, Choi J W, Kim S B, Park S J and Kim D J 2009 Two-dimensional modelling of benzene transport and biodegradation in a laboratory-scale aquifer; Environ. Tech. 30 53-62.

Chu M, Kitanidis P K and McCarty P L 2007 Dependence of lumped mass transfer coefficient on scale and reactions kinetics for biologically enhanced NAPL dissolution; $A d v$. Water Resour. 30 1618-1629.

Clement T P, Wise W R and Molz F J 1994 A physically based, two-dimensional, finite-difference algorithm for modeling variably saturated flow; J. Hydrol 161 71-90.

Clement T P, Gautam T R, Lee K K, Truex M J and Davis G B 2004 Modeling of DNAPL-dissolution, rate-limited sorption and biodegradation reactions in groundwater systems; Bioremed. J. 8(1-2) 47-64.

English C W and Loehr R C 1991 Degradation of organic vapors in unsaturated soils; J. Hazard. Mater. 28 55-63.

Fredlund D G and Xing A 1994 Equations for the soil-water characteristic curve; Can. Geotech. J. 31 521-532.

Frind E O, Molson J W and Schiemer M 1999 Dissolution and mass transfer of multiple organics under field conditions: The Borden emplaced source; Water Resour. Res. 35(3) 683-694.

Hendry M J, Wassenaar L I and Birkham T K 2002 Microbial respiration and diffusive transport of $\mathrm{O}_{2},{ }^{16} \mathrm{O}_{2}$, and ${ }^{18} \mathrm{O}^{16} \mathrm{O}$ in unsaturated soils: A mesocosm experiment; Geochim. Cosmochim. Acta 66 3367-3374.

Hinchee R E, Downey D C, Dupont R, Aggarmal P and Miller R N 1991 Enhancing biodegradation of petroleum hydrocarbons through soil venting; J. Hazard. Mater. 27 315-325.

Kampbell D H, Snyder C B, Downey D C and Hansen J E 2001 Light nonaqueous-phase liquid hydro-carbon weathering at some JP-4 fuel release sites; J. Hazard. Subst. Res. 4-1(3) 1-7. 
Kim D J, Choi J W, Choi N C, Mahendran B and Lee C E 2005 Modeling of growth kinetics for Pseudomonas spp. during benzene degradation; Appl. Microb. Biotech. 69 456-462.

Kim S B, Park C H, Kim D J and Jury W A 2003 Kinetics of benzene biodegradation by Pseudomonas aeruginosa: Parameter estimation; Environ. Toxicol. Chem. 22 1038-1045.

Kim H, Annable M D and Rao P S C 2001 Gaseous transport of volatile organic chemicals in unsaturated porous media: Effect of water-partitioning and air-water interfacial adsorption; Environ. Sci. Technol. 35 44574462.

Kinzelbach W, Schäfer W and Herzer J 1991 Numerical modeling of natural and enhanced denitrification processes in aquifers; Water Resourc. Res. 27(6) 11231135.

Lahvis M, Baehr A L and Baker R J 1991 Quantification of aerobic biodegradation and volatilization rates of gasoline hydrocarbons near the water table under natural attenuation conditions; Water Resour. Res. 35 753-765.

Lee M S, Lee K K, Hyun Y, Clement T P and Hamilton D 2006 Nitrogen transformation and transport modeling in groundwater aquifers; Ecol. Modeling 192 143-159.

Lehmann F and Ackerer P H 1998 Comparison of iterative methods for improved solutions of the fluid flow equation in partially saturated porous media; Transport in Porous Media 31 275-292.

Lin J and Hildemann L M 1995 A nonsteady-state analytical model to predict gaseous emissions of volatile organic compounds from landfills; J. Hazard. Mater. 40 271-295.

Mastrocicco M, Colombani N, Sbarbati C and Petittam M 2012 Assessing the effect of saltwater intrusion on petroleum hydrocarbons plumes via numerical modelling; Water Air Soil Poll. 223 4417-4427.

Mayer A S and Miller C T 1996 The influence of mass transfer characteristics and porous media heterogeneity on nonaqueous phase dissolution; Water Resour. Res. 32(6) 1551-1567.

Mayer K U, Frind E O and Blowes D W 2002 Multicomponent reactive transport modeling in variably saturated porous media using a generalized formulation for kinetically controlled reactions; Water Resour. Res. 38(9) 1174 .

Miller C T, Poirier-McNeill M M and Mayer A S 1990 Dissolution of trapped nonaqueous phase liquids: Mass transfer characteristics; Water Resour. Res. 26(11) 2783-2796.

Millington R J 1959 Gas diffusion in porous media; Science 130 100-102.

Mitchell R J and Mayer A S 1998 A numerical model for transient-hysteretic flow and solution transport in unsaturated porous media; J. Contam. Hydrol. 50 243-264.

Mualem Y 1976 A new model for predicting the hydraulic conductivity of unsaturated porous media; Water Resour. Res. 12 513-522.

Nambi I M and Powers S E 2003 Mass transfer correlations for nonaqueous phase liquid dissolution from regions with high initial saturations; Water Resour. Res. 39(2) 1-11.

Nassar I N, Ukrainczyk L and Horton R 1999 Transport and fate of volatile organic chemicals in unsaturated, nonisothermal, salty porous media: 2. Experimental and numerical studies for benzene; J. Hazard. Mater. B69 $169-185$.

Natarajan N and Suresh Kumar G 2011 Numerical modelling of bacteria facilitated contaminant transport in fractured porous media; Colloids and Surfaces A: Physico. Engg. Aspects 387 104-112.
Ojha C S P, Hari Prasad K S, Ratha D N and Surampalli Y 2012 Virus transport through unsaturated zone: Analysis and parameter identification; J. Hazard. Toxic Radioactive Waste 15(2) 96-105.

Overman A R 1975 Ion transport through sand by convective diffusion; Plant and Soil 43 663-670.

Phoon K K, Tan T S and Chong P C 2007 Numerical simulation of Richard's equation in partially saturated porous media: Under-relaxation and mass balance; Geotech. Geol. Engg. 25 525-541.

Popovicova J 1996 Transport of gas-phase contaminants in the unsaturated zone; Ph.D Dissertation, The University of Arizona, USA.

Powers S E, Abriola L M and Weber W J 1994 An experimental investigation of non-aqueous phase liquid dissolution in saturated subsurface systems: Transient mass transfer rates; Water Resour. Res. 30(2) 321332.

Powers S E, Loureiro C O, Abriola L M and Weber W J 1991 Theoretical study of the significance of nonequilibrium dissolution of nonaqueous phase liquids in subsurface systems; Water Resour. Res. 27(4) 463-477.

Purandara B K, Varadarajan N and Venkatesh B 2008 Simultaneous transport of water and solutes under transient unsaturated flow conditions - A case study; Earth Syst. Sci. 117(4) 477-487.

Reible D D, Malhiet M E and Illangasekare T H 1989 Modelling gasoline fate and transport in the unsaturated zone; J. Hazard. Mater. 22 359-376.

Richards L A 1931 Capillary conduction of liquids through porous mediums; Physics 1 318-333.

Rivett M O and Feenstra S 2005 Dissolution of an emplaced source of DNAPL in a natural aquifer setting; Environ. Sci. Technol. 39 447-455.

Schaerlaekens J, Venderborght J, Merckx R and Feyen J 2000 Surfactant enhanced solubilization of residual trichloroethene: An experimental and numerical analysis; J. Contam. Hydrol. 46 1-16.

Simunek J and Suarez D L 1994 Two-dimensional transport model for variably saturated porous media with major ion chemistry; Water Resour. Res. 30(4) 1115-1133.

Sulaymon A H and Gzar H A 2011 Experimental investigation and numerical modeling of light nonaqueous phase liquid dissolution and transport in a saturated zone of the soil; J. Hazard. Mater. 186 1601-1614.

Unger A J A, Forsyth P A and Sudicky E A 1998 Influence of alternative dissolution models and subsurface heterogeneity on DNAPL disappearance times; J. Contam. Hydrol. $30217-242$.

Van Dam J C and Feddes R A 2000 Numerical simulation of infiltration, evaporation and shallow groundwater levels with the Richards equation; J. Hydrol. 233 $72-85$.

van Genuchten M Th 1980 A closed-form equation for predicting hydraulic conductivity of unsaturated soils; Soil Sci. J. 44(5) 892-898.

Vasudevan M, Suresh Kumar G and Nambi I M 2014 Numerical modeling of multicomponent LNAPL dissolution kinetics at residual saturation in a saturated subsurface system; Sadhana, doi: 10.1007/s12046-014-0282-1.

Voudrias E A and Li C 1993 Benzene vapor transport in unsaturated soil: Adequacy of the diffusion equation; J. Hazard. Mater. 34 295-311.

Weaver J W 1996 Application of the hydrocarbon spill screening model to field sites; Conference on Nonaqueous Phase Liquids in the Subsurface Environment: Assessment and Remediation; Proceedings of the American Society of Civil Engineers, Washington DC, USA. 
Xiang-Wei H A N, Ming-An S H A O and Horton R 2010 Estimating van Genuchten model parameters of undisturbed soils using an integral method; Pedosphere 20(1) 55-62.

Yadav B K and Hassanizadeh S M 2011 An overview of biodegradation of LNAPLs in coastal (semi)-arid environment; Water Air Soil Poll. 220 225-239.
Yang Y R and McCarty P L 2000 Biologically enhanced dissolution of tetrachloroethene DNAPL; Environ. Sci. Technol. 34 2979-2984.

Zeng X and Decker M 2009 Improving the numerical solution of soil moisture-based Richards equation for land models with a deep or shallow water table; J. Hydrometeorol. 8(3) 447-468. 